Review article

\title{
Genetic variation and breeding strategies for improved cell wall digestibility in annual forage crops. A review
}

\author{
Yves BARRIÈRE ${ }^{a *}$, Carine GuILLET ${ }^{\mathrm{a}}$, Deborah GOFFNER ${ }^{\mathrm{b}}$, \\ Magalie PICHON ${ }^{b}$
}

\begin{abstract}
${ }^{a}$ Unité de Génétique et d'Amélioration des Plantes Fourragères, INRA, 86600 Lusignan, France
b UMR CNRS UPS Signaux et Messagers Cellulaires Végétaux, 31326 Castanet-Tolosan, France
\end{abstract}

(Received 14 October 2002; accepted 18 March 2003)

\begin{abstract}
Forage plants are the basis of ruminant nutrition, and cell wall digestibility is the limiting factor of their feeding value. Cell wall digestibility is therefore "the" target for improving the feeding value of forage crops. Among annual forages, maize cropped for silage making is the most widely used, and much research in genetics, physiology and molecular biology of annual forages is devoted to maize. Sorghum, immature small grain cereals and straws of small grain cereals are also given to cattle. Some dicotyledons are or were also used, such as forage beets, kales, canola in temperate areas and amaranths in tropical and subtropical areas. Large genetic variation for cell wall digestibility was proved from both in vivo and in vitro experiments in numerous species. Among the regular maize hybrids (excluding brown-midrib ones), the NDF in vivo digestibility nearly doubled from 32.9 to $60.1 \%$. Correlations between in vivo and in vitro estimates of cell wall digestibility were often close to 0.75 , but in vitro estimates of cell wall digestibility significantly reduced the range of variation between genotypes. Despite lignin content is well known as the major factor making cell wall undigestible, breeding for a higher digestibility of plant only from a lignin content trait appeared impossible. Correlations between lignin content and cell wall digestibility were indeed greatly variable according to the genetic background. Moreover, enzymatic solubilities were excessively dependent on lignin, and correlation between in vivo estimates of cell wall digestibility and lignin content were always lower than correlation between in vitro estimates of cell wall digestibility and lignin content. Among brown-midrib genes, the bm 3 mutant in maize, and the bmr12 (and possibly bmr18) mutant in sorghum, which are both altered in the COMT activity, appeared as the most efficient in cell wall digestibility improvement. Moreover, a great genetic variation in the efficiency of the maize bm 3 gene for cell wall digestibility improvement was observed according to the genetic background, with a lower efficiency when the normal germplasm was of better cell wall digestibility. Efficient breeding maize and others annual forage plants demands a renewing of genetic resources. Because resources of interest in cell wall digestibility improvement could be of poor agronomic value, the best is likely to
\end{abstract}

\footnotetext{
* Correspondence and reprints

Tel.: 33 (0)5 495560 32; fax : 33 (0)5 495560 44; e-mail barriere@lusignan.inra.fr
} 
use a marker assisted selection, after identifying alleles of interest in these resources. Results obtained on forage plants and model plants strengthened also the interest of genetic engineering in the lignin pathway for improving the cell wall digestibility of forage plants.

cell wall digestibility / ingestibility / annual forage / maize / genetic variation / breeding / lignin

Résumé - Amélioration de la digestibilité des parois des fourrages annuels. Les plantes fourragères sont à la base de l'alimentation des ruminants, mais leur valeur nutritive est limitée par la digestibilité variable des parois végétales, dont l'amélioration est alors la cible essentielle des programmes de sélection. Parmi les fourrages annuels, le maïs est la plante la plus cultivée, et c'est sur cette espèce que porte l'essentiel de la recherche en génétique, physiologie et biologie moléculaire. Toutefois, le sorgho, les céréales à paille et des dicotylédones comme les betteraves, les choux, les colza en régions tempérées et les amarantes en zones tropicales sont également utilisées comme plantes fourragères. Une importante variabilité de la digestibilité des parois végétales a été mise en évidence pour de nombreuses espèces, à la fois à partir de mesures in vivo ou in vitro. Ainsi, pour le maïs (sans plantes bm3), la digestibilité in vivo du NDF varie du simple au double entre 32,9 et $60,1 \%$. Les corrélations entre les estimations in vivo et in vitro de la digestibilité des parois sont en général de l'ordre de 0,75 , mais les estimations in vitro de la digestibilité réduisent significativement la gamme de variation entre génotypes. Alors que la teneur en lignine est le facteur majeur d'ingestibilité, il n'est toutefois pas possible de sélectionner pour une digestibilité plus élevée à partir des teneurs en lignine. Les corrélations entre teneur en lignine et digestibilité des parois sont en effet très variables en fonction du fond génétique. De plus, les solubilités enzymatiques apparaissent exagérément liées à la teneur en lignine, avec des corrélations entre teneur en lignine et digestibilités in vitro bien supérieures à celles observées avec les digestibilités in vivo. Parmi les mutants à nervures brunes, les mutants bm 3 du maïs et bmr12 du sorgho (et peut-être bmr18), avec des mutations liées à la COMT, sont apparemment les plus efficaces en terme d'amélioration de la digestibilité. Il existe par ailleurs une variabilité de l'effet du gène bm 3 du maïs en fonction du fond génétique, avec une efficacité plus élevée quand le géniteur de départ est de plus faible digestibilité. Un progrès génétique significatif pour la digestibilité des parois des fourrages annuels nécessite un renouveau important des ressources génétiques habituellement utilisées. La mise en évidence des allèles d'intérêt pour la digestibilité des parois et leur introduction par sélection assistée par marqueurs évitera les pertes de valeur agronomique lié à l'utilisation de ressources dépassées par ailleurs. Enfin, au vu des données actuellement disponibles sur plantes modèles et plantes d'intérêt agronomique, il ne faudrait pas sous-estimer l'intérêt du génie génétique pour l'amélioration de la digestibilité des parois végétales.

digestibilité des parois / ingestibilité / fourrage annuel / maïs / variabilité génétique / amélioration génétique / lignine

\section{INTRODUCTION}

Forage plants are the basis of ruminant nutrition, but although forages contain almost the same amount of gross energy as do grains per unit of dry matter, the energy value of forages is lower and much more variable, ranging approximately from $80 \%$ (leafy ray-grass) to $33 \%$ (wheat straw) of maize grain value. This difference results from the high content of cell wall in forage plants, and to the limited digestion of this fiber part by the micro-organisms of rumen and, to a lesser degree, of large intestine of animals. Lignins are the cell wall part resistant to fungal and bacterial degradation. Because of their quantitative importance in the cell wall, of their variable structure, and of the way in which they embed and bind to hemicelluloses and cellulose, lignins have a variable depressive effect on carbohydrate degradation by micro-organisms. 
Most spontaneous or cropped forages are perennial plants, and are mainly grasses. For annual forages, maize cropped for silage making is the most widely used. Because of the economic importance of the "corn" crop worldwide, and of the economic importance of forage maize in $\mathrm{Eu}-$ rope, much research in genetics, physiology and molecular biology of annual forages is devoted to maize, and there are extensive data available. Sorghum and immature small grain cereals (wheat, barley, triticale...) are also given to cattle, either as green plants, but often after ensiling. Straws, including rice straws in tropical areas, are also sometimes used for cattle feeding after grain harvest. All these major annual forage plants are monocotyledons. Some dicotyledons such as forage beets and kales were used in temperate areas and given as fresh plant to cattle, but this is not longer done due to the cost of harvesting and difficulties in conservation. Rape-seed or canola forages are also used in cattle feeding, grazed, given fresh or ensiled. Amaranths are widely grown as a leafy vegetable for human feed in tropical and subtropical areas, but some cultivars are highly prized as forage crops, because of their rapid growth rate, good yielding, and high protein content. Annual grain legumes of temperate areas, such as peas, are also, but rarely, used as green forages of high protein content. Despite its fiber crop origin, kenaf has been viewed as an alternative forage crop with a high drought tolerance.

A significant part of this review will deal with investigations of cell digestibility variation in cattle, and with relationships between in vivo and in vitro results, because a breeding strategy based on in vitro criteria has to be first validated in vivo. Genetic resources, including specialty plants, will be investigated to highlight the most suitable germplasm for breeding plants of higher feeding value. A subsequent part of the review will develop a tentative breeding strategy based on the available data on cell wall traits related to feeding value for ruminants, and genetic advances or methodologies in plant breeding. The focus of this review will be on maize, as there are little data available on cell wall digestibility improvement in other annual forage crops. However, whenever possible, information on other annual forage crops will be reported.

\section{CELL WALL DIGESTIBILITY IS "THE" TARGET FOR THE IMPROVEMENT OF FORAGE FEEDING VALUE}

The part of available energy in a forage that is effectively used by an animal has been proved strongly correlated to the forage digestibility. The energy supplied by a forage in a ruminant or herbivore animal diet is thus related to the forage ingestibility and digestibility. The digestibility of any forage constituent (dry matter, organic matter, or cell wall) is usually measured as the percentage of each constituent that has disappeared in the animal digestive tract. The ingestibility of a forage is the quantity that is taken by an animal when this forage is offered ad libitum, as an unique meal. Ingestibility is usually measured as $\mathrm{kg}$ DM per animal and per day, but can also be considered as $\mathrm{g} \cdot \mathrm{kg}^{-1}$ of metabolic weight (live weight ${ }^{0.75}$ ). When a plant is fed to an animal, ingestibility and digestibility are plant characteristics resulting of cell wall development, and are subject to plant genetic variation.

Assuming a normal efficiency of the rumen micro-organisms, the variation in energy feeding value of a forage plant is related (i) to the variation in digestibility of the stover part of the plant, and therefore to the variation in cell wall digestibility, (ii) to the variation in grain content, if grains, that are a highly digestible part, are present in the forage (maize, sorghum, ...), (iii) to the digestive interactions between the forage and the concentrates present in 
the diet and (iv) to the variation in ingestibility, that is related to the transit rate of particles out of the rumen, and then to the intensity and rate of particles degradation.

Cell wall digestibility is "the" target for improving the feeding value of forage crops. This is obvious when the harvested plant has no grain, particularly as soluble carbohydrates are subject to extensive environmental variation. But it is also true in maize silage, for three independent reasons. Firstly, in vitro digestibility of the whole maize plant has most often been proved to correlate better with stover cell wall digestibility than with grain content. From Deinum and Bakker [80], Deinum and Struik [82], Wolf et al. [183] and data reviewed by Cox et al. [74], correlations between maize whole plant digestibility and cell wall (or stover) digestibility ranged from 0.60 to 0.96 , with average values close to 0.80 , whereas correlations between whole plant digestibility and grain or ear content were only nearly equal to 0.45 . In vivo genetic correlations obtained at INRA Lusignan (France) corroborated these results. In vivo organic matter digestibility (OMD) correlated most $\left(\mathrm{r}_{\mathrm{g}}=0.77\right)$ with in vivo NDF digestibility (NDFD), whereas the correlation with starch content was lower $\left(r_{g}=0.54\right)$. Moreover, NDFD and ear or starch content were found to be independent traits $\left(r_{g}=0.09\right)$, as also observed by Deinum and Struik [82] with $\mathrm{r}=-0.01$. NDFD and starch content both explained at least $90 \%$ of the genetic variation in OMD, while the remaining percent points were probably related to the variation in soluble carbohydrates content, and to the imprecision of the estimates. The second reason why cell wall digestibility is the leading target to improve the feeding value of forage crops is related to animal digestive physiology. Due to rumen micro-organism ecology and due to acidosis risks, whatever the conditions of ruminant cattle feeding, the optimal grain content in a cereal silage has to be adjusted according to the extra starch content of the diet, and according to the proportion of by-pass starch. The optimum starch content in maize was thus proved to be close to $30 \%$ in European conditions of dairy cattle rearing $[28,37]$. This result, which was proved in maize, is very likely true in other immature cereals. Finally, a higher NDF digestibility should result in higher energy intake by cattle, even if the DM intake has not been affected [145]. An efficient genetic progress in feeding value is then intrinsically related to NDFD improvement, both for forages with and without grain.

\section{IN VIVO GENETIC VARIATION FOR CELL WALL DIGESTIBILITY IN ANNUAL FORAGE CROPS}

\subsection{In vivo genetic variation for cell wall digestibility in maize}

The reference value of a forage digestibility is established through measurements with animals, and mostly often with sheep (adult wethers) in digestibility crates. Most often, work has been devoted to studies of whole plant digestibility, and only few studies have investigated cell wall digestibility. The first digestion trials in Europe with ensiled forage maize seem to be those of Dijktra and Becker ([87], quoted in [81]) in the Netherlands, and those of Demarquilly [83], and Andrieu and Demarquilly [8], in France. From 25 measurements reported by Deinum et al. [81], OMD of silage maize had an average value of $72.8 \%$. The average NDF in vivo digestibility (NDFD) of hybrids was $52.7 \%$, and ranged from 47.5 to $57.1 \%$ (NDFD of one bm 3 hybrid was also $65.1 \%$ ). Andrieu and Demarquilly [7] reported an OMD in maize silage equal to $71 \%$ that could reach $74 \%$, according to cropping conditions, maturity and/or grain content. The NDFD of hybrids involved in this French study was later estimated to $53.1 \%$, and ranged from 49.8 to $54.8 \%$ [27]. 
From 50 maize silages cropped between 1971 and 1993, De Boever et al. [78, 79] reported average OMD values equal to $74.7 \%$. The average crude fiber digestibility (CFD) of these hybrids was $66.3 \%$ and ranged from 60.4 to $74.6 \%$ (de Boever, personal communication), corresponding approximately to NDFD values equal to 61.4 , 56.1 , and $68.8 \%$, respectively. Most of these forage maize in vivo reference values, thus estimated more than 30 years ago, were based on a limited number of early genotypes with good feeding value (Fronica, Circé, LG11, but not Eta Ipho, in the Netherlands, and Inra258, Funk245, Dekalb204, LG11 in France), which are no longer representative of the presently available hybrids.

Many measurements with sheep in digestibility crates have been made on a much wider genetic basis at INRA Lusignan (and first reported in [33]). Today, data are available from measurements of 2100 mini-silos and 431 hybrids with an average 34\% dry matter content at harvest. Among these hybrids, 167 were experimental hybrids and 264 were registered hybrids, representative of all seed companies present on the French and North European markets. Genetic variation in OMD and NDFD of silage maize were thus proved to be very large (Tab. I).
Among the regular maize hybrids (excluding brown-midrib ones), the NDFD nearly doubled from 32.9 to $60.1 \%$, and it was similar for the sub-sample of registered hybrids for which the NDFD went from 32.9 to $58.4 \%$. Among the 220 registered early hybrids, the range in NDFD was 19 percent points. Among the 41 registered late studied varieties, the range in NDFD was 14.9 percent points. Late hybrids had an average NDFD (46.1\%) slightly lower than early hybrids $(48.0 \%)$, but a few late hybrids had also a much lower cell wall digestibility (the minimum value was $32.9 \%$ ) than early hybrids (the minimum value was $39.4 \%$ ). Genetic correlations between NDFD and other traits related to feeding value are given in Table II. The correlation between NDF content and NDFD was close to zero. No significant relationship existed between the cell wall digestibility and the cell wall content when maize plants were thus harvested at a similar maturity stage. Consequently, for a given starch content, OMD was only related to NDFD. The genetic progress in feeding value was thus directly related to NDFD improvement. The narrow sense heritability of in vivo digestibility traits was high $\left(\mathrm{h}^{2}>0.70\right)$, and assuming a selection intensity of $25 \%$, the genetic progress in NDFD was expected to

Table I. In vivo genetic variation for OMD and NDFD in maize hybrids, including experimental, but not brown-midrib, hybrids, and hybrids registered in Europe between 1958 and 2000. Average dry matter content of silage $34.8 \%$.

\begin{tabular}{|c|c|c|c|c|c|c|}
\hline & $\begin{array}{l}\text { Hybrid } \\
\text { number }\end{array}$ & $\sigma_{\mathrm{g}}^{2}$ & $\sigma_{\mathrm{r}}^{2}$ & Mean & Mini & Maxi \\
\hline All normal hybrids & 388 & & & & & \\
\hline OMD & & 2.4 & 2.7 & 69.7 & 61.3 & 75.9 \\
\hline NDFD & & 4.3 & 15.3 & 48.6 & 32.9 & 60.1 \\
\hline All registered hybrids & 264 & & & & & \\
\hline OMD & & 2.3 & 2.5 & 69.6 & 61.3 & 74.3 \\
\hline NDFD & & 4.5 & 14.9 & 48.0 & 32.9 & 58.4 \\
\hline
\end{tabular}

OMD: organic matter digestibility; NDF: neutral detergent fiber; NDFD: NDF digestibility. 
Table II. Genetic correlations between traits related to in vivo feeding value of maize hybrids.

\begin{tabular}{lccc}
\hline & NDFD & OMD & $\begin{array}{c}\text { Starch } \\
\text { content }\end{array}$ \\
\hline OMD & 0.77 & - & \\
Starch content & 0.09 & 0.54 & - \\
NDF content & -0.06 & -0.66 & -0.74 \\
\hline
\end{tabular}

For abbreviations, see Table I.

be equal to 5.4 percent points per breeding cycle.

Based on European or Northern America experiments, the genetic variation in the NDFD value of maize silage was also proved to have consequences on young bull or dairy cow performances, even if maize was not the only constituent of the diet, [35, $36,53,95,118,120]$. All other factors being equal, when comparing hybrids with poor or good cell wall digestibility in dairy cows, fat corrected milk (FCM) yields differed from 1 to $3 \mathrm{~kg}$ among hybrids. The protein contents in milk were also equal or higher in hybrids that allowed greater milk yields. In a similar way, differences in average daily gains of young bulls reached $100 \mathrm{~g}$ per day among hybrids. When it was investigated, differences between hybrids found in cows were often slightly lower than expected according to their estimated value with standard sheep, despite the fact that Aerts et al. [3] showed no systematic differences between sheep and cows in the measurement of digestibility.

Genotype $\times$ environment interactions affect both the extent of genetic progress in plant breeding and the efficiency of variety choice by farmers. From a specific experiment in 14 locations [12], in vivo CFD genotype $\times$ environment interaction was non significant, whereas the location and genotype main effects were highly significant. Genotype $\times$ environment interactions could be also investigated from a sub-sample of the measurements in the 2100 mini-silos and 431 hybrids fed to sheep. Data were then considered for only 703 mini-silos, corresponding to 35 hybrids studied over 5 or more years, with at least 2 replicates per year (Tab. III). The genotype effect for NDFD was highly significant $(P<0.001)$, whereas the NDFD genotype $\times$ year interaction was not significant. For OMD, genotype $\times$ year interactions were significant, but the mean-square was about 10 times lower than the mean-square of the genotype effect. This was related to high interactions observed for starch content. Genotype $\times$ year interactions were also significant for NDF content, but this could only be related to the variation in starch content, as these two values were expressed in percentage of the total dry matter. Therefore, maize breeders are able to improve maize feeding value from estimates of NDFD, after maize cropping in a limited number of locations and/or years, provided the locations are well chosen, and provided a relevant in vitro criterion is available.

\subsection{In vivo genetic variation for cell wall digestibility in other annual forage crops}

Cell wall digestibility was lower in sorghum silages than in maize silages, especially in sweet $\times$ grain sorghum hybrids, and OMD was also much lower (Tab. IV).

Table III. Genotype $\times$ year interactions computed for in vivo measurements of traits related to feeding value, over 32 years, 35 genotypes and 703 mini-silos of maize silage (INRA Lusignan unpublished data, MS is the mean-square; **: $P<0.001 ; *: P<0.01)$.

\begin{tabular}{lccc}
\hline & $\begin{array}{c}\text { Genotype } \\
\text { MS }\end{array}$ & $\begin{array}{c}\text { Genotype } \\
\times \text { year MS }\end{array}$ & $\sigma_{\mathrm{r}}^{2}$ \\
\hline NDFD & $265.4^{* *}$ & $23.7 \mathrm{~ns}$ & 17.5 \\
OMD & $46.8^{* *}$ & $4.5^{*}$ & 2.8 \\
Starch & $33.8^{* *}$ & $17.5^{* *}$ & 5.5 \\
NDF & $25.3^{* *}$ & $12.3^{* *}$ & 5.2 \\
\hline
\end{tabular}

For abbreviations, see Table I. 
Table IV. In vivo genetic variation for OMD and NDFD in different type of sorghum hybrids (INRA Lusignan unpublished data).

\begin{tabular}{lcccc}
\hline & $\begin{array}{c}\text { Genotype } \\
\text { number }\end{array}$ & Mean & Mini & Maxi \\
\hline Grain sorghum & 5 & 65.2 & 62.5 & 67.2 \\
OMD & & 45.2 & 40.1 & 49.1 \\
NDFD & & & \\
& & & \\
Grain $\times$ sweet sorghum & & 57.8 & 54.4 & 60.1 \\
OMD & & 40.8 & 44.9 & 52.3 \\
NDFD & 3 & & & \\
& & & 53.7 & 58.2 \\
Sudan grass $\times$ sorghum & & 55.9 & 47.1 & 51.3 \\
OMD & & & & \\
NDFD & & & & \\
\hline
\end{tabular}

For abbreviations, see Table I.

Sorghum silage appeared to have maximum NDFD or OMD values that were much lower than the highest values of maize, despite the fact that some grain sorghum silages had a higher grain content than maize. Aydin et al. [18] also reported that most studies that compared sorghum with maize silage have shown that milk production was consistently higher for cows fed the maize silage than for those fed the sorghum silage, which was of lower cell wall digestibility. Few data were available for genetic variation in cell wall digestibility of small grain cereals. However, the variation in feeding values of straws of different varieties of cereal crops affected the performance of lactating cows, lactating sheep and steers $[51,147,156$ quoted in 52]. Garnsworthy and Stokes [100] reported a modified ADF in vivo digestibility of oat silage ranging from $46 \%$ (45 days after emergence) to $41 \%$ (65 days after ear emergence). From INRA Lusignan unpublished data, average NDFD in triticale and wheat were close to $49 \%$, and close to $46 \%$ in rye, but low or very low intakes were observed with awned plants (especially all triticale lines), which very likely led to overestimated NDFD values. The cell wall digestibility of rape-seed and canola, both for green forage and silage, was closely related to the stage of harvest. Rape-seed CFD in sheep was very high in leafy stages, nearing $90 \%$, but swiftly decreased towards $50 \%$ as stems developed [94]. Winter type genotypes were more suitable for cattle feeding than spring types, as their leafy stage lasted longer. No difference in digestibility and/or growth performance of cattle was observed between genotypes with high or low glucosinolates content [94, 131]. Demarquilly and Andrieu [85] gave an average OMD of forage kale close to $83 \%$, related to the weak crude fiber content of this forage, but also likely related to its good cell wall digestibility. Compared to others grasses and forage crops, the cell wall digestibility of maize or sorghum varied little during the period of ensiling compared to great degrees in variation of cell wall digestibility in other forage crops, due to the rapid increase in stem content. 


\section{GENETIC IMPROVEMENT OF CELL WALL DIGESTIBILITY IN ANNUAL FORAGE CROPS FROM IN VITRO TRAITS}

\subsection{Devising a breeding criterion for genetic improvement of cell wall digestibility}

For obvious practical and financial reasons, digestibility assessments have to be performed using in vitro tests of dry matter, organic matter, or cell wall digestibility. Moreover, this plant digestibility value must be easily and accurately predicted through NIRS. But this approach is pertinent only if the in vitro method used is proved to be a good predictor of animal behavior. For maize breeders, in large trial networks, a cheap and easy digestibility test also has to be devised on whole plant samples, without separating grain from stover, or leaf from stalk. When using an enzymatic solubility on whole plant samples, a given digestibility value can be related to large grain or soluble carbohydrate contents, but with a low digestibility of cell walls, or from a higher digestibility of the stover, with lower starch or soluble carbohydrate contents. Breeding forage plant for feeding value makes it therefore necessary to assess at the same time the digestibility of the whole plant, and to have the possibility of assessing or computing the digestibility of the cell wall part.

The in vitro digestibility of plant was first estimated through the Tilley and Terry [170] method, using rumen fluid. This method was later modified by Goering and van Soest [103], Marten and Barnes [138], Craig et al. [75] and recently by Lauer et al. [133]. NIRS calibrations for Tilley and Terry modified tests with rumen fluid were developed by Lauer et al. [133], and also in labs in the Netherlands. Different whole plant enzymatic solubilities (IVDMD) were developed in Europe by Aufrère, [16], slightly modified by Aufrère and Michalet-
Doreau, [17], Lila et al. [135], De Boever [77], and Ronsin and Femenias [157]. Correlations between these different IVDMD were very high $(r>0.90)$, but the mean value of the Aufrère and Michalet-Doreau IVDMD is about 5 percent lower than the others, with an approximately $25 \%$ lower residual error (Barrière et al., unpublished data). NIRS calibrations of all these IVDMD were computed and available at CRA Libramont (Belgium). For maize official registration, De Boever et al. [77] or Aufrère and Michalet-Doreau [17] IVDMD are used in Belgium, France, Germany, and the United Kingdom, whereas in the Netherlands and in Switzerland, digestibility of maize for official registration is estimated through a Tilley-Terry test. For all INRA data reported here, IVDMD was assessed with the Aufrère and Michalet-Doreau [17] method.

For plant breeding purpose, and from results on maize, cell wall digestibility can be cheaply computed using three different estimates, based on a Tilley-Terry test or on an enzymatic solubility of the whole plant (both predicted through NIRS calibrations). According to Struik [167] and Dolstra and Medema [89], the in vitro NDF digestibility (IVNDFD) is computed assuming that the non-NDF part of plant material is completely digestible. According to Argillier et al. [11], the in vitro digestibility of the "non starch and non soluble carbohydrates" part (DINAG, or English acronym IVDNSC) is computed assuming that starch and soluble carbohydrates were completely digestible. A modified DINAG criterion, namely DINAGZ, was later estimated in a similar way as DINAG, after adding the crude protein to the completely digestible constituents [30]. The formula are

IVNDFD $=100 \times($ IVDMD $-(100-\mathrm{NDF})) /$ NDF

$\mathrm{DINAG}=100 \times(\mathrm{IVDMD}-\mathrm{ST}-\mathrm{SC}) /$

$(100-\mathrm{ST}-\mathrm{SC})$ 
DINAGZ $=100 \times($ IVDMD $-\mathrm{ST}-\mathrm{SC}-$ $\mathrm{CP}) /(100-\mathrm{ST}-\mathrm{SC}-\mathrm{CP})$

where ST, SC and $\mathrm{CP}$ are starch content, soluble carbohydrate content and crude protein content, respectively. These estimates of cell wall digestibility have proved their great relevance and efficiency in plant breeding [11, 15, 24, 90, 133, 160]. However, IVNDFD does not give the true NDF digestibility value, and these three estimates are not relevant in interspecific comparisons. Moreover, the values of cell wall digestibility obtained with any of these estimates could be seriously biased if anti-nutritional compounds such as tannins have an impact on non-fiber digestibility.

The use of a Tilley-Terry estimate of plant digestibility rather than an enzymatic solubility could be questioned, both when estimating whole plant IVDMD, and when computing cell wall IVNDFD or DINAGZ. Obviously, the enzymatic methods are easier and cheaper, as they do not require the maintenance of animals producing rumen fluid. Only few data are seemingly available giving correlations between TilleyTerry and enzymatic IVDMD. From data of Capper et al. [52] investigating 30 barley genotypes, the correlation between a pepsin-cellulase and the Tilley-Terry digestibility was only 0.49 . De Boever et al. [78] reported a correlation $r=0.84$ between a Tilley-Terry and a pepsin-cellulase IVDMD, from measurements in 50 maize silages. From measurements on numerous maize samples, Van Waes [178] reported correlations between pepsin-cellulase and Tilley-Terry digestibility equal to $0.60,0.55$ and 0.88 in each of the 3 years of experiments, respectively. In the German network for forage maize evaluation, the correlation was close to 0.84 , observed from about 100 samples both in 1998 and 1999 (Tillmann, personal communication). Over a large range of variation in digestibility values, a European maize breeder (personal communication) also observed a correlation close to 0.80 , but this correlation fell to 0.50 when only genotypes with average or good cell wall digestibility were taken into consideration. Differences between rumen fluid digestibility and enzymatic solubility also arose from the study of De Boever et al. [78] on 50 maize silages, since correlations were higher between enzymatic IVDMD and ADL $(r=-0.81)$ than between TilleyTerry digestibility and ADL $(r=-0.66)$.

\subsection{Genetic variation in cell wall digestibility estimated from in vitro criteria}

Much research has proved that there are large genetic variations in the in vitro digestibility of maize, either for whole plants or cell wall parts, and both in inbred lines and hybrids (reviews in $[15,37]$ ). When considering the digestibility of whole plants, as well as cell wall digestibility (even if the latter was less frequently studied), additive genetic effects for in vitro values of digestibility were preponderant over more complex genetic effects. Similarly, genotype $\times$ environment interactions for cell wall digestibility were very often small compared to main effects. Heritabilities of quality traits were high, ranging between 0.65 and 0.80 , and at least equal to those of yield $[10,72,160]$. The heritability of DINAG and DINAGZ was always greater than that of IVDMD, and equal or higher than heritability of IVNDFD. Breeding for higher in vitro cell wall digestibility value should therefore be very efficient, and the expected progress for the first selection cycle of breeding for cell wall digestibility could easily reach 3.0 percent points.

According to Garnsworthy and Stokes [100], some comparisons have been made on the effects of species, varieties and times of harvest on the quality of small grain cereals for silage. Notably, Tingle and Dawley [172] reported differences in IVDMD between varieties of barley and between varieties of oats harvested at the soft-dough stage. Large differences in IVDMD of 
barley straw were also reported by Capper et al. [52], but no data were available for cell wall digestibility. Varietal differences in IVDMD of rice straw have been reported from many countries and have been first summarized by Doyle et al. [91]. Vadiveloo [177] observed later a whole plant IVDMD ranging from 23.6 to 36.9 in rice straws, when the IVDMD of stems ranged from 27.6 to $43.3 \%$. Agbagla-Dohnani et al. [4] observed an in sacco degradability of organic matter in straws of 15 rice varieties ranging from 23.6 to $35.6 \%$. Genetic variation in cell wall digestibility of rice straw was first reported by Abou-el-Enin [2] from 53 varieties in 5 Oryza species. NDF digested after a $48 \mathrm{~h}$ in sacco incubation ranged from 21.2 to $31.1 \%$, and varieties with high or low IVNDFD were found within each species group. It is doubtful if the cell wall digestibility of straw could be used directly as a breeding criterion in small grain cereal improvement programs, but identification of varieties with consistently better straws is of interest to determine the most economical use of straw for cattle feeding, especially in areas where straws represent an important part of the animal diet.

Large morphological diversity exists amongst kales and cabbages. Given that four generations of half-sib family breeding for a higher yield of IVDOM in an initial population which included different types of kales and cabbages, led to a population of marrow-stem kale, Bradshaw and Mackay [47] concluded that this was the type of kale most suitable for the simultaneous improvement of yield and feeding value. From Kunelius et al. [129], IVDMD of a marrow kale variety was indeed very high all along the season, close to $92 \%$ from 110 to 185 days after sowing, whereas lignin content remained low and increased only from 2.5 to $3.5 \%$. These results were in agreement with in vivo estimates of Demarquilly and Andrieu [85]. No cell wall digestibility of green forage brassicas was seemingly published, but, computed from data of Kunelius et al. [129], IVNDFD of kale remained high and close to $71 \%$ during the 110 to 185 day period after sowing. This plant, that withstands low temperature during autumn and early winter, is probably underrated in cattle feeding, but this may be related to the labor costs of harvesting and foddering.

The forage nutritive value of amaranths was considered by Sleugh et al. [164] to be equal to or better than commonly used forage in IVDMD, with an average value across genotype and harvest date equal to $71.1 \%$. Amaranths have also a high crude protein content $(14.5 \%)$, which have high digestibility and quality (amino acid composition and content in bypass protein). For 7 species or ecotypes, harvested from 42 to 112 after planting, average NDF content was $37.4 \%$, but average IVNDFD was low, nearing only $27.7 \%$, and this could be related to the $\mathrm{C} 4$ anatomy of amaranth plants. Average IVNDFD remained close to $25 \%$ from 42 to 84 days after planting, and neared $20 \%$ from this date. The optimum harvest date was probably close to 84 days after planting, when the IVNDFD was still close to $25 \%$, and the nitrate and oxalate concentrations were sufficiently low in fresh forage to avoid toxicity risks in animals. Ensiling the forage was considered as an alternative for reducing the nitrate concentration and then improving its digestibility ([55] quoted in [164]). Out of the genotypes studied by Sleugh et al. [164], A hybrid and A hybridus had the higher IVNDFD at 84 days ( $28 \%$ on average), but had the lowest protein content (11\%). A hypochondriacus (from Colorado), which was also the species with the lowest ADL content 84 days after planting, probably gave a better compromise between IVNDFD (23\%), IVDMD and protein content $(14 \%)$. In any case, and according to Kauffmann ([125], quoted in [164]), A hypochondriacus is an amaranth cultivated solely for use as forage for cattle, and an 
improvement in its cell wall digestibility would very likely be possible. The search for Amaranths adapted to temperate areas could also be considered as an alternative answer in countries facing difficulties in crude protein supplies for cattle feeding.

Contradictory results were published on kenaf as a forage plant. Xiccato et al. [184] showed that digestibility was low in the apical portion of full blooming kenaf. They also established that kenaf silage was unpalatable and often refused by ewes. But Muir et al. [144] considered that the overall plant digestibility of kenaf, harvested 60 to 120 days after planting, compared favorably with traditional forages in semiarid regions. The genotypic effect was significant for in sacco NDF disappearance (ISNDFD), with an average value close to 50\% [144]. Low palatability to cattle, often cited as limiting the use of kenaf as a forage plant, was considered as more related to initial rather than long term difficulties, as illustrated by observation of favorable intake rates relative to those of alfalfa ([114], quoted in [144]).

\subsection{Relationships between estimates of in vitro cell wall digestibility in maize lines and hybrids}

Both during elite hybrid breeding, for QTL analysis, or for evaluation of genetic resources, it is easier and cheaper to have whole plant and cell wall digestibility estimates in lines rather than after top-crossing. Moreover, variance of traits is greater in lines than in hybrids. Gurrath et al. [111] reported correlation between maize inbreds and hybrids stover digestibility, and ADL content, at silage harvest equal to 0.75 , and 0.81 , respectively. Wolf et al. [183] reported a correlation between S2 families per se value and average top cross value (two testors) for cell wall digestibility equal to 0.62 in whole plant. Dolstra et al. [90] reported a correlation between mid-parent and hybrid stalk cell wall digestibility equal to 0.70 . Argillier et al. $[11,15]$ established also good or very good relationships between lines per se and top cross values in two factorial designs. Correlations between hybrid values and per se values ranged between 0.76 and 0.94 for DINAG, and between 0.63 and 0.87 for lignin content. On the contrary, the correlation between hybrid values and line values was very low for starch content $(r=0.28)$. In a RIL progeny study [160], correlations between cell wall digestibility estimates in RILs per se and top cross were high $(\mathrm{r}=0.71$ and 0.79 for DINAGZ and IVNDFD, respectively), and these correlations were, as expected, higher than for IVDMD $(r=0.63)$. Correlation between lignin content in RILs per se and top cross was higher for ADL/NDF $(r=0.75)$ than for KL/NDF $(r=0.62)$. Correlations between RILs per se and top cross were also high for other constituents of NDF, such as Hemicellulose/NDF $(r=0.78)$ and Cellulose/NDF $(r=0.81)$, but lower for NDF content $(\mathrm{r}=0.58)$. All these results proved the feasibility of preliminary tests from lines per se value in breeding for the improvement of forage cell wall digestibility in maize. This is very likely true in other hybrid forage plants.

\subsection{Relationships between in vitro and in vivo cell wall digestibility traits in maize}

Much research has focused on the relationships between whole plant Tilley-Terry or enzymatic IVDMD, and whole plant in vivo OMD, in order to elaborate practical rules for cattle feeding. Zimmer et al. ([185], quoted in [186]) reported in maize a quadratic regression between OMD and Tilley-Terry IVDMD with a correlation $r=0.80$. Givens et al. [102] obtained a correlation $r=0.80$ from 4 sets of maize silage originating from the UK, the Netherlands and Belgium (and a total of 106 silages) between OMD and an enzymatic neutral detergent cellulase OMD. De Boever et al. $[78,79]$ reported a correlation $\mathrm{r}=0.82$ from 
50 maize silages between OMD and enzymatic IVDMD. Andrieu et al. [9] observed a correlation only equal to 0.57 between OMD and IVDMD, but, despite 234 measurements were achieved in sheep, only 15 hybrids were used and harvested about 7 times from early milky stage to a grain near maturity stage. These results highlighted that in vitro estimates of whole plant digestibility explained only a part, nearing $60 \%$, of the variation observed in cattle. But, while OMD and IVDMD have been significantly investigated, very few papers have reported data on intra-specific relationships between in vitro and in vivo cell wall digestibility estimates. Argillier et al. [13], in an experiment with 58 maize hybrids studied for both in vivo and in vitro digestibility values, gave a correlation equal to 0.55 between CFD in sheep and DINAG. From a study with 36 maize silages, De Boever (personal communication) obtained a correlation $r=0.67$ between CFD and Tilley-Terry IVDNFD, and a correlation $\mathrm{r}=0.55$ between CFD and an IVNDFDr (estimate obtained from incubation of a NDF residue with a cellulase), in a very good agreement with the observations of Argillier et al. [13].

However, correlations between in vivo and in vitro values for whole plant and cell wall digestibility were also recently studied on a much larger genetic basis in an InraProMaïs network [24]. For 4 years, 165 maize hybrids were cropped in a balanced, but incomplete, design with 2 replicates per year and per genotype in Lusignan, allowing the making of 560 mini-silos (one mini-silo per hybrid and replicate). Feeding values of these hybrids were estimated through sheep experiments. Enzymatic solubility and biochemical constituents were measured on green forage, in samples taken during harvesting. Genotype effects were highly significant for in vivo traits OMD, NDFD, for in vitro IVDMD or DINAGZ, and for ADL/NDF content, even when bm3 hybrids were not taken into consideration in the variance analysis (Tab. V). The correlation between OMD and IVDMD was $\mathrm{r}=$ 0.74 , in agreement with values observed by Givens et al. [102] and De Boever et al. [79]. The correlation was $r=0.75$ between NDFD and DINAGZ, in good agreement with correlations observed by Argillier et al. [13] or De Boever (personal communication). Average values were equal in OMD and IVDMD, or NDFD and DINAGZ, respectively, but the in vitro solubility heavily reduced the range of variation between hybrids (Tab. V). Among normal hybrids, the minimum - maximum range was 27 percent points in NDFD, but only 12 percent points in DINAGZ. However, the greater range of variation in cell wall digestibility observed in vivo was partly balanced by the higher error observed for NDFD than that for DINAGZ. In vivo measurements of cell wall digestibility were less precise than in vitro estimates, as it was previously reported by Deinum et al. [81]. But, greater errors in NDFD than in DINAGZ were probably also related to the necessity of measuring, both in silage and in feces, the NDF content, which had a slightly high standard deviation.

In vitro methods are screening tools for determining the relative differences among forages, and the real concern is that in vivo and in vitro methods rank forages in a similar order. As it was observed for whole plant digestibility, in vitro estimates of cell wall digestibility only explained $60 \%$ of the variation observed in cattle. For breeding purpose, both NDFD and DINAGZ criteria lead efficiently and similarly to the elimination of hybrids with poor cell wall digestibility, or to the choice of good hybrids such as the bm 3 ones, or normal hybrids close to the bm 3 ones. However, from a simulation of a hybrid choice performed in the INRA Lusignan database, the selection of hybrid with intermediate cell wall digestibility could partly differ according to the NDFD or DINAGZ trait used. The ranking of hybrids, within a reduced variation range of cell wall 
Table V. Genetic variation in in vivo and in vitro traits related to feeding value, observed from 560 mini-silos and 165 genotypes with bm3 hybrids, and 494 mini-silos and 149 genotypes without bm3 hybrids. In vivo traits were measured on silage, whereas in vitro traits were measured on green forage sampled at harvest $(* *: P<0.001)$.

\begin{tabular}{lccccc}
\hline & OMD & NDFD & IVDMD & DINAGZ & ADL/NDF \\
\hline bm3 hybrids included & & & & & \\
MS genotype & $15.3^{* *}$ & $83.0^{* *}$ & $20.4^{* *}$ & $38.4^{* *}$ & $2.7^{* *}$ \\
MS genotype $\times$ year & 3.4 & 21.5 & 4.0 & 3.2 & 0.2 \\
$\sigma_{\mathrm{r}}^{2}$ & 2.4 & 12.7 & 3.0 & 3.1 & 0.1 \\
& & & & \\
Mean & 70.8 & 51.2 & 71.0 & 50.5 & 6.2 \\
Mini & 62.4 & 35.7 & 65.6 & 44.0 & 3.2 \\
Maxi & 77.0 & 66.4 & 78.2 & 60.2 & 7.7 \\
Standard deviation & 1.6 & 3.8 & 1.8 & 1.9 & 0.3 \\
\hline Without bm3 hybrids & & & & & \\
MS genotype & $8.7 * *$ & $38.3 * *$ & $9.0^{* *}$ & $11.6 * *$ & $0.5^{* *}$ \\
MS genotype $\times$ year & 3.5 & 22.8 & 3.9 & 2.2 & 0.1 \\
$\sigma_{\mathrm{r}}^{2}$ & 2.5 & 13.0 & 3.1 & 3.1 & 0.1 \\
& & & & & \\
Mean & & & & & \\
Mini & 70.4 & 50.1 & 70.5 & 49.6 & 6.4 \\
Maxi & 62.4 & 35.7 & 65.6 & 44.0 & 5.2 \\
\hline
\end{tabular}

For abbreviations, see Table I; IVDMD: whole plant enzymatic solubilities; DINAGZ: in vitro digestibility of non starch, non carbohydrate and non crude protein parts; ADL: acid detergent lignin.

digestibility, was nonetheless partly different with DINAGZ and NDFD, as these two traits did not cover the same part of digestibility variation found in plant fed to cattle. Similar results were, as expected, obtained when simulated choices were based on OMD or IVDMD, respectively, because NDFD was the major determinant factor of OMD.

These results raised the question of the interest in having a NIRS calibration of the in vivo NDFD estimate of cell wall digestibility. From the data set quoted above, preliminary results [24] proved the feasibility of such a cell wall calibration, with a $r^{2}$ value equal to 0.63 for NDFD, with a standard error of cross validation (SECV) equal to 3.4. No other attempt to calibrate NDFD seems to have been reported. However, a first experimental calibration was built up by Biston et al. [43] for silage maize OMD, with a standard error of prediction equal to 1.6 and $\mathrm{r}^{2}$ value equal to 0.60 . A slightly better result was obtained for OMD from our data set, with a SECV equal to 1.4 and a $\mathrm{r}^{2}$ value equal 0.68 . An alternative strategy in cell wall digestibility computing through the IVNDFD criterion could then be proposed, as suggested by Dardenne (personal communication), using an OMD value calibrated in NIRS rather than an IVDMD 
value. The limit of procedures based on animal values is the necessity to have an experimental sheep flock, in order to get annual reference data requested for NIRS calibration maintenance. However, the number of reference measurements could decrease as the robustness of the calibration could increase after each year of experiments.

\subsection{Breeding from cell wall digestibility traits or from lignification traits}

Lignin content is well known as the major factor making cell wall undigestible. The interest of working simply with a lignification trait, rather than with a more complex cell wall digestibility trait, could thus be questioned in plant breeding for improved digestibility traits. However, for such an objective, it is absolutely essential to evaluate lignin content as a part of the cell wall, NDF for example, and not as a part of the whole plant (DM or OM). If not, the lignin content is largely biased due to the variation in soluble carbohydrates or starch content. Moreover, the choice between a cell wall digestibility trait or a lignification trait has to be considered from in vivo and in vitro values of digestibility, because relationships between digestibility and lignification could be different in in vivo or in vitro traits.

Correlations between NDFD and lignin content were also available from the experiment based on 560 mini-silos and 165 maize hybrids [24]. Correlations between NDFD and ADL/NDF or LK/NDF were $r=-0.75$ and $r=-0.65$, respectively, with bm 3 genotypes, and $\mathrm{r}=-0.45$ and $\mathrm{r}=$ -0.25 , respectively, without bm 3 genotypes. But, in the same set of data, the correlations between DINAGZ and ADL/NDF or KL/NDF were much higher, with $\mathrm{r}=$ -0.94 and $r=-0.75$, respectively when bm 3 hybrids were included, and $\mathrm{r}=-0.88$ and $\mathrm{r}=$ -0.45 , respectively, without bm3 hybrids. From a sub-sample of 19 maize silages among the 50 studied, De Boever (personal communication) observed similarly a correlation $\mathrm{r}=-0.39$ between NDFD and ADL.

Wolf et al. [183] reported correlations between maize stover IVNDFD and permanganate lignin content equal to -0.86 , -0.37 and -0.64 in a set of 24 S2 family and their top cross by 2 inbred lines, respectively. In Lundvall et al. [136], and from a study of 45 maize lines, the correlation between ADL/NDF and IVNDFD was equal to -0.62 . Méchin et al. [139] observed a genetic correlation only equal to -0.51 between ADL/NDF and IVNDFDr in basal stalks of a set of 18 normal maize lines whose IVNDFDr ranged between 25.7 and $38.0 \%$. The correlation was $r=-0.80$ when 4 bm 3 hybrids were added. From a 3 year experiment with 125 early and medium early inbred lines harvested at silage maturity stage, whose DINAG value ranged from 53.0 to 64.5 (68.7 with bm3), and whose ADL/NDF value ranged from 1.29 to 4.69 (0.56 with bm3) [14], the correlations between DINAG and ADL/NDF were $\mathrm{r}=-0.79$, and $\mathrm{r}=-0.72$, with and without 6 bm3 lines, respectively. From a study of cell wall digestibility in RIL progenies [160], the correlation between DINAGZ and $\mathrm{ADL} / \mathrm{NDF}$ or KL/NDF in lines per se were $r=-0.93$ and -0.63 , respectively, and were in top cross $r=-0.86$ and -0.34 , respectively. Unpublished results at INRA Lusignan showed a correlation $r=-0.33$ between ADL/NDF and DINAGZ in stover of a set of 23 normal maize lines, whose DINAGZ values ranged from 43.1 to $60.9 \%$. This correlation increased up to -0.47 when $2 \mathrm{bm} 3$ lines were added.

All these results highlighted a great variation in correlations between lignin content and cell wall digestibility depending on the method used in lignin content estimation, and depending on the germplasm involved. The correlation between ADL/NDF and a cell wall digestibility trait appeared to be even greater given that the genetic basis of 
compared genotypes was more homogeneous, as within a RIL progeny or a set of registered or elite hybrids. It was also the case when bm 3 genotypes were added, mainly increasing the range of variation and then the linkage between the two traits. The lignin content could explain only 20 to $50 \%$ of the in vivo variation in cell wall digestibility, but often more than $50 \%$ of the in vitro variation in cell wall digestibility. The ADL/NDF value also appeared as a measure of the part of lignin mainly involved in the indigestibility of the cell wall, whereas the KL/NDF value measured a whole lignin content of the plant cell wall. However, when breeding normal lines or hybrids, a large part of the DINAGZ variation remained unexplained by the ADL/ NDF value, and the genetic unexplained part could reach $75 \%$ among normal lines of diverse origins. This unexplained part corresponded to variation in lignin structure and cell wall phenolics involved in cell wall digestibility. Moreover, because the correlation between cell wall digestibility and lignin content of the cell wall was much higher for in vitro data than for in vivo, in vitro solubilities has probably led to an overestimated effect of lignin content on cell wall digestibility. These results have highlighted the main disadvantage of enzymatic solubilities, which are excessively dependent on lignin content. The variation in lignin content and in lignin structure may have induced non-proportional mechanical effects, and/or non proportional effects on the rate of degradation, that could not be approached through an in vitro test, or at least, through their actual in vitro estimates. Breeding for cell wall digestibility improvement cannot be based only on a lignin content trait, and must also involve a cell wall digestibility trait. Another great disadvantage of breeding with ADL/NDF rather than with a DINAGZ trait is the weaker relationship observed between lines per se value and top cross value for lignin content, compared to the relationship observed between lines and hybrids for cell wall digestibility traits [15].

\section{IN VIVO GENETIC VARIATION FOR INGESTIBILITY IN ANNUAL FORAGE CROPS}

\subsection{Plant traits related to variation for intake in ruminant cattle}

Voluntary intake is a primary nutritional factor controlling animal production. Ruminants consuming diets high in cell wall content often are unable to eat sufficient quantities of forage to meet their energy demands. Dry matter content of the silage is an important factor of intake variation, and optimum water contents have been established, allowing a good conservation, a good palatability and a good intake of every forage (32 to $37 \%$ dry matter content in maize silage). For a given dry-matter content, ingestibility is the plant trait, subject to genetic variation, estimated in animals as intake. But, due mostly to the great impossibility for plant breeders to work with cattle, and in agreement with Minson and Wilson [142], there was "a failure of most scientists to recognize the importance of voluntary intake, that has led to an unnecessary and undesirable gulf between the science and the practice". Moreover, intake responses are not totally similar in sheep and in cows, and intake response by an animal depends also on its energy needs [60, $84,92,143]$. The regulation of an animal's appetite is above all a physical regulation. The ingestibility of a given forage is controlled by the time this forage is retained in the rumen (reviews in [122, 142]). Particles have to be broken down a size close to $1 \mathrm{~mm}$ before they can go out of the rumen through the digestive tract. Chewing during eating and ruminating is responsible for most of this breakdown of particle in chopped forage [142]. As a consequence, the filling capacity of a forage, and hence its ingestibility, 
depends on (i) the rate of particle size reduction while animal is eating and ruminating; (ii) the rate and extent of ruminal degradation of the cell wall constituents; and (iii) the rate of passage of small particles out of the rumen through the reticulo-omasal orifice, which also depends on the functional specific gravity of the particles.

\subsection{Variation in ingestibility and relationships with genetic variation in cell wall digestibility}

When fed to cattle, intake of maize hybrids of significantly lower cell wall digestibility was lower than the intake of hybrids of rather good cell digestibility $[35,36,53$, 95]. Although it has been reported in very few experiments, some hybrids have indeed a higher intake in dairy cows. A better ingestibility was shown by Ciba-Semences $[64,65]$ in the kindred hybrids Briard and Bahia, close to 0.5 and $1.0 \mathrm{~kg}$, respectively, compared to a commonly used hybrid. The voluntary intake of hybrid DK265, which is of good cell wall digestibility, was proved to be greater than that of other hybrids [24, $35]$. When maize silage was given as about $80 \%$ of the diet, dairy cows fed a DK265 silage had an average intake reaching nearly $1.5 \mathrm{~kg} \cdot \mathrm{day}^{-1}$ more than hybrids with the same dry matter and grain contents, and, in two comparing experiments, with the same cell wall digestibility. Intake of DK265 appeared indeed much closer to that of bm3 hybrids than to that of normal hybrids.

The effect of cell wall digestibility on intake was also proved in inter-specific comparisons. Cummins and McCullough [76], and Aydin et al. [18] reported that most studies that compared sorghum with maize silage have shown that DM intake was consistently higher for cows fed the maize silage than for those fed the sorghum silage, with lower cell wall digestibility. The average dry matter intake of sorghum silage was $81 \%$ that of maize, when fed to heifers in the Cummins and McCullough [76] experiment. In a diet including $35 \%$ of sorghum or maize silage, respectively fed to dairy cows, the average dry matter intake of the sorghum silage diet was $85 \%$ that of the maize silage diet, whereas the IVNDFD of sorghum silage was $75 \%$ that of maize [18].

\subsection{Devising a breeding criterion for genetic improvement of ingestibility}

The composite structure of many thick-walled and lignified cells in vascular, sclerenchyma strands and parenchyma cells between bundles, in both leaves, shanks and stems makes fiber particles physically strong and difficult to reduce in size [142]. As a consequence, it is obviously difficult to create a direct prediction tool for estimating hybrid ingestibility. Minson and Wilson [142] reported old studies on the mechanical resistance of tissue to grinding as correlated with intake $[59,132]$. They also reported the development of a mechanical masticator by Troelsen and Bigsby [174], giving encouraging results, but this technique was not used later because "it was so laborious". Simpler methods were later developed for breeding higher ingestible forages [19], but seemingly without significant further use. According to Minson and Wilson [142], Blaxter et al. [44] first reported that voluntary intake was positively correlated with digestibility, and Hawkins et al. [115] reported that voluntary intake was negatively correlated with lignin content. The rate of NDF degradation, measured in situ in fistulated animals, varied very significantly among genotypes [38, 124]. Such a trait should be considered as being possibly related to a genotype's rumen-filling capacity, and as a consequence, to genotype ingestibility. However, from later results [24], the ranking of hybrids for parameters of the degradation kinetics was not sufficiently related to the ranking of hybrids for 
their ingestibility, and these parameters did not appear to be useful for the improvement of maize ingestibility.

From preliminary results [24], the best multiple regression for the prediction of intake by cows included as first regressor the NDFD measured in sheep, and then the energy content of the silage (also from sheep measurements), with a $\mathrm{r}^{2}$ value slightly higher than 0.6 (for a given DM content). Even if the rate of breakdown is a main factor of voluntary intake regulation, the cell wall digestibility improvement is probably a main target for ingestibility improvement, all the more because it could be assumed that the sheep NDFD included a component related to particle friability. These results are an a posteriori justification of the priority given to studies on digestibility. The improvement of cell wall digestibility in maize (and very likely in other forage plants) will also bring about an improvement in ingestibility. However, some specific and unknown characteristics in hybrids such as DK265 have to be elucidated. Today, mapping QTL traits related to lignification and cell wall digestibility is probably the best way to highlight the important traits involved in maize ingestibility. This could be considered more specifically in related RIL progenies including, or not, a parental line of hybrids such as DK265.

\section{BROWN MIDRIB PLANTS AND IMPROVEMENT OF DIGESTIBILITY AND INGESTIBILITY IN ANNUAL FORAGE CROPS}

\subsection{Brown-midrib plant discovery and main traits}

The brown midrib plants exhibit a reddish brown pigmentation of the leaf midrib and stalk pith, associated with lignified tissues, since the plants have about five expanded leaves. Until now, and according to
Cherney et al. [63], brown midrib phenotypes were only seen in maize, sorghum and millet, which are all diploid monocotyledons belonging to the Panicoideae subfamily. As reported by Jorgenson [121], the first brown midrib maize plant appeared in a self-pollinated line of a northwestern dent maize in 1924. The gene was subsequently named bm1 and three other genes inducing the brown midrib phenotype were described later, as bm 2 by Burnham and Brink [48], bm3 by Emerson [93], and bm4 by Burnham [49]. Each bm1, bm2, bm3, or bm4 gene originates from natural mutations and segregates as a simple mendelian recessive character. The effect of maize brown midrib mutations on lignin content was first evidenced by Kuc and Nelson [127]. A few years later, the effect of these mutants on forage feeding value (digestibility or ingestibility) was first evidenced by Barnes et al. [23] from in vitro studies. In sorghum, 19 independently occurring brown midrib mutants were identified in segregating progenies of chemically treated seeds of two lines by Porter et al. [151]. Some of the mutant lines had a significantly reduced lignin content, and/or a significantly higher in vitro digestibility of cell wall constituents. Brown midrib mutants in pearl millet also originated from chemically induced mutations [61]. Many studies were then made on brown midrib plants, used as models in digestibility and lignification studies (reviews in $[26,63,123]$ ).

\subsection{Genetic improvement of cell wall digestibility and ingestibility in brown-midrib crops}

Most experiments evaluating the improvement in performances of cattle fed brown midrib plants were based on the maize bm 3 mutant. The effect of the bm 3 mutation on forage maize feeding value (digestibility or ingestibility) was first demonstrated in vivo by Colenbrander et al. [69, $70,71]$, through a comparison of intake and 
growth of heifers fed on normal maize and on bm 3 maize. Different experiments with lactating cows have been reported since this work (Tab. VI), but it would seem that no experiment of cattle rearing with bm 3 genotypes were done between 1987 and 1998 . The intake of bm 3 silage by dairy cows was always higher than the intake of normal silage, even if the difference was not always significant (and for dairy cattle, the apparent benefit of the bm 3 mutation is from increased silage intake). This characteristic was recently observed with an experimental medium early bm3 hybrid that was ingested $2.1 \mathrm{~kg} \cdot \mathrm{day}^{-1}$ more than the average of 10 control hybrids, and $0.6 \mathrm{~kg}$ more than the highly ingestible normal hybrid DK265 [24]. Higher milk yield of cows fed bm 3 hybrids were reported in eleven out of fifteen experiments, ranging from 0.5 to $3.3 \mathrm{~kg} \cdot \mathrm{day}^{-1}$ (Tab. VI). Milk yields were not significantly lower in four experiments. Moreover, every time this trait was recorded, increase of body weight was observed in cattle fed bm 3 silage. Hybrids with very good digestibility and ingestibility, such as bm 3 hybrids, could indeed appear to be no more efficient than normal hybrids in dairy cows, when maize silage is too small an ingredient in the diet, or when supplying

Table VI. Feeding efficiency of bm 3 maize silage in dairy cattle, from experiments published since 1976. Comparisons were done between isogenic hybrids, except in Bal et al. [20] and Ballard et al. [22], $\left[\mathrm{Conc}=\right.$ concentrates, $\mathrm{IVNDFD}=$ in vitro $\mathrm{NDF}$ digestibility, $\mathrm{FCM}=$ fat corrected milk at $3.5^{\circ}$ or $4.5^{\circ 0} \%, \mathrm{CP}=$ crude protein, $\mathrm{ADG}=$ average daily gain $\left.\left(\mathrm{g} \cdot \mathrm{day}^{-1}\right)\right]$.

\begin{tabular}{|c|c|c|c|c|c|c|c|c|c|}
\hline & $\begin{array}{c}\text { Year of } \\
\text { publication }\end{array}$ & $\begin{array}{l}\text { Silc } \\
(\% \text { C } \\
\mathrm{N} \\
\end{array}$ & $\begin{array}{l}\text { age } \\
\text { diet) } \\
\text { bm3 }\end{array}$ & $\begin{array}{c}\text { Conc. } \\
\left(\mathrm{kg} \cdot \mathrm{day}^{-1}\right) \\
\text { bm3-N }\end{array}$ & $\begin{array}{c}\text { IV } \\
\text { NDFD } \\
\text { bm3-N }\end{array}$ & $\begin{array}{l}\text { Maize } \\
\text { intake } \\
\text { bm3-N }\end{array}$ & $\begin{array}{c}\text { FCM } \\
\text { bm3-N }\end{array}$ & $\begin{array}{c}\text { Milk } \\
\text { CP(\%) } \\
\text { bm3-N }\end{array}$ & $\begin{array}{c}\text { ADG } \\
\text { bm3-N }\end{array}$ \\
\hline Frenchick et al. [97] & 1976 & 49 & 49 & 0.0 & - & 0.2 & $-0.1^{\circ}$ & - & 88 \\
\hline Rook et al. [158] & 1977 & 60 & 60 & 0.0 & - & 1.1 & $-0.1^{\circ}$ & 0.10 & 14 \\
\hline Rook et al. [158] & 1977 & 85 & 85 & 0.0 & - & 2.7 & $0.7^{\circ}$ & -0.02 & 42 \\
\hline Keith et al. [126] & 1979 & 75 & 75 & $0.0^{(1)}$ & 10.5 & 0.6 & $0.9^{\circ}$ & 0.0 & - \\
\hline Sommerfeldt et al. [165] & 1979 & 55 & 57 & 0.0 & 10.0 & 0.7 & $-0.5^{\circ}$ & -0.04 & 106 \\
\hline Block et al. [45] & 1981 & 65 & 65 & 0.0 & - & 3.5 & $1.2^{\mathrm{oo}}$ & 0.08 & 755 \\
\hline Stallings et al. [166] & 1982 & 49 & 47 & - & 15.0 & 0.6 & $-0.6^{00}$ & - & 80 \\
\hline Hoden et al. [116] & 1985 & 80 & 80 & 0.2 & 8.9 & 1.0 & $0.7^{00}$ & -0.11 & 165 \\
\hline Hoden et al. [116] & 1985 & 78 & 86 & -1.3 & 8.9 & 1.7 & $0.5^{\circ 0}$ & 0.12 & 0 \\
\hline Weller and Phipps [181] & 1986 & 69 & 70 & 1.3 & 14.6 & 0.6 & $3.3^{\circ 0}$ & -0.0 .6 & 90 \\
\hline Oba and Allen [145] & 1999 & 45 & 45 & $0.0^{(2)}$ & 9.7 & 2.1 & $2.6^{\circ}$ & 0.04 & 100 \\
\hline Bal et al. [20] & 2000 & 32 & 40 & $-3.6^{(3)}$ & - & 0.0 & $0.5^{\circ}$ & -.0 .06 & 40 \\
\hline Oba and Allen [146] & 2000 & 51 & 56 & -1.3 & 9.4 & 1.4 & $3.2^{\circ}$ & 0.03 & 20 \\
\hline Tine et al. [171] & 2000 & 60 & 60 & 0.0 & $7.0^{(4)}$ & 2.4 & $1.7^{\circ}$ & 0.12 & 170 \\
\hline Ballard et al. [22] & 2001 & 31 & 31 & 0.0 & 10.9 & 0.5 & $2.5^{\circ}$ & -0.01 & - \\
\hline
\end{tabular}


the usual quantity of concentrates. An excess in available energy is then partly converted by cows into weight gain (meat or fat tissue). Experiments of Hoden et al. [116], Bal et al. [20], and Oba and Allen [145] clearly supported the hypothesis that the higher potential of such hybrids can only be fully expressed when the supply of energy concentrates is lower, taking into account the extra intake of silage, and taking into account the higher energy value of bm3 hybrids.

Comparisons involving the other different maize brown-midrib genes with meat or dairy cattle are very rare. The bm 1 and bm 3 mutation in an isogenic background were compared for the feeding of young bull [34]. Compared to bulls fed with the normal Inra260 hybrid, the average daily carcass gain was $39 \mathrm{~g} \cdot \mathrm{day}^{-1}$ higher in bulls fed Inra $260 \mathrm{bm} 1$, but was $137 \mathrm{~g} \cdot$ day $^{-1}$ higher in bulls fed Inra260bm3. This result, corroborating measurements of cell wall digestibility in sheep, clearly established the much higher efficiency of the bm 3 mutant for cattle feeding. The digestibility and the interest in cattle feeding of bm4, and on a lower scale, of bm 2 hybrids, remain unclear.

Lusk et al. [137], Grant et al. [107], and Aydin et al. [18] reported different experiments with brown midrib sorghum in the diets of dairy cows. DM intake and milk yield were always lower in standard sorghum diets than in brown midrib sorghum diets. Brown midrib sorghum resulted indeed in milk production similar to normal maize silage. In a palatability trial with a 4 week regrowth, grazing lambs displayed a marked preference for the brown-midrib pearl millet, compared to normal [62]. When normal or brown-midrib pearl millet were fed to wethers, average NDFD over two cutting were 67.7 and $71.0 \%$ in normal and brown midrib plants, respectively [62].

Whatever the involved species (maize, sorghum or pearl millet), and whatever the in vitro test used (Tilley-Terry or enzymatic solubility methods), the higher digestibility of brown midrib plants was also always found. Results were doubtless similar for lignin content. Using three chemically induced mutants, selected by Porter et al. [151] for the further experiments, Fritz et al. [99] showed an improvement in stem IVDMD ranging between 8 and $12 \%$ in brown midrib sorghum, compared to normal sorghum. From their results, the ADL/NDF was reduced by $1.3,2.2$ and 2.5 percent point in bmr6 (BC2), bmr12 and bmr18 (BC1) sorghum, compared to normal, respectively. But IVNDFD was only improved by $3.1,5.2$ points in bmr6 and bmr12, respectively, and, surprisingly 1.6 percent in bmr18, due to a lower NDF content in brown midrib mutants. Watanabe and Kasuga [180] observed a higher digestible structural matter (DSM) in bmr12 and bmr18 sorghum (close to $49.6 \%$ ), than in bmr6 (42.4\%), and they considered that these brown midrib sorghum were 10-15\% higher in DSM than in comparable normal sorghum. From Akin et al. [6], IVNDFD of two pearl millet stems was on average 13.2 percent points higher than that of the isogenic line. Many similar results were also published for maize brown midrib mutants, and most of them were reported in the reviews already mentioned. However, compared to other maize brown midrib mutants, the maize bm 3 mutant appeared to be especially improved in cell wall digestibility. Grand et al. [106] established the quasilack of COMT (caffeic acid O-methyl transferase) activity in bm3 plants, and Vignols et al. [179] established that the bm3 mutation corresponded to a deletion or a large insertion of a retrotransposon element in the exon 2 of the COMT gene. Sorghum bmr12, and perhaps bmr18, mutants likely brought similar improvement in cell wall digestibility to the maize bm 3 mutant, and appeared also altered in their COMT activity [112, 130]. Similarly, an Arabidopsis mutant with a knocked-out COMT gene had also a highly improved cell wall digestibility of floral stems [105]. Conversely to COMT mutants, sorghum bmr6 and pearl 
millet bmr mutants probably had an efficiency similar to that of the maize bm1 mutant, which is altered in the CAD (cinnamylic alcohol deshydrogenase) activity [113]. New mutants of interest for feeding value (brown midrib or not) should be found through lignin or IVNDFD measurements when using a transposon tagging method, in search of genes involved in lignification and cell wall biogenesis, whatever the (diploid) species used as a model.

\subsection{Genetic variation for cell wall digestibility among bm 3 maize genotypes}

Genetic variation was found among bm3 hybrids, as backcrossing the bm 3 gene in different genetic backgrounds did not lead to similar improvement in cell wall digestibility. Gentinetta et al. [101] evaluated $21 \mathrm{bm} 3$ hybrids of a $7 \times 7$ semi-diallel mating of late maize lines, and their normal isogenic counterparts. Variation for lignin content was significant in bm 3 hybrids, and ranged from 3.1 to $5.0 \%$, whereas lignin content varied significantly from 5.3 to $6.8 \%$ in normal hybrids. Moreover, lignin content in bm 3 hybrids ranged from 50.8 to $74.8 \%$ of the content observed in the isogenic hybrid, with a weak correlation between lignin content in normal hybrids and in their bm 3 isogenics $(r=0.48)$. In a set of 12 experimental hybrids made from crossing early and medium late inbred lines [39], the average NDFD improvement between normal and bm3 hybrids was 8.5 percent points, but the NDFD improvement ranged from 4.4 to 17.9 percent points. Similarly, from a comparison of 14 experimental and formerly or more recently registered hybrids (Barrière et al., unpublished data), the range of NDFD went from 43.4 to $55.8 \%$ (12.4 percent points) in normal hybrids, and from 52.0 to $63.4 \%$ (11.4 percent points) in bm3 isogenic hybrids. The NDFD improvement brought by the bm3 gene ranged from to 5.3 to 12.3 percent points, with an average value of 8.4 percent points. The correlation between NDFD values in normal and bm 3 hybrids was only 0.65 . Moreover, the correlation between the NDFD in normal hybrids and the NDFD improvement given by the bm 3 gene in each hybrid was -0.40 . All these results proved an effect of the genetic background on the NDFD improvement obtained with the bm 3 gene, with a tendency to a lower efficiency of the mutant gene when normal hybrids were of higher cell digestibility. Similar results were observed in vitro in lines [14]. The range of DINAG in 7 early flint and dent bm 3 maize lines was only 2.4 percent points, lower than the 7.4 percent point range observed between the isogenic normal lines. But, as it was observed in hybrids, there was also a great variation in improvement between lines as the DINAG value was increased by 10.7 percent points in F271bm3, but only by 5.2 percent points in $\mathrm{F} 113 \mathrm{bm} 3$ or $\mathrm{W} 117 \mathrm{bm} 3$, with a similar tendency to a lower efficiency of the bm 3 gene when normal lines were of higher DINAG. Specific effects of the genetic background should be considered when the bm3 gene was used for improving the cell wall digestibility. But this variation never cancelled the interest of the bm3 mutation for the cell wall digestibility improvement, especially as the efficiency of the mutation seemed greater when the feeding value of the normal genotype was lower.

\subsection{Towards an improvement of agronomic value in brown midrib forage crops}

The higher efficiency of bm 3 maize for cattle feeding was indeed clearly established, as soon as in the 1980's, but for a long time, breeders were disappointed by the lower yield, irregular earliness, and susceptibility to lodging of bm 3 hybrids. The recent and renewed interest in bm 3 hybrids for dairy cattle feeding (references in 
Tab. VI), or for growing steer feeding [173], especially in the USA, became possible because of the great improvement in agronomic value of normal hybrids in the last 25 years. This renewed interest may also be related to the low feeding value of the parental lines used in modern medium late and late hybrids. With normal hybrids of good standability, whose potential yield ranges between 17 and $20 \mathrm{t} \cdot \mathrm{ha}^{-1}$, it is conceivable to breed isogenic or close bm 3 hybrids whose yield will be reduced by about 3 $\mathrm{t} \cdot \mathrm{ha}^{-1}$, but whose NDFD will be increased by about 8 percent points. Ballard et al. [22] and Cox and Cherney [73] reported a yield reduced by 2 to $3 \mathrm{t} \cdot \mathrm{ha}^{-1}$, with an IVNDFD improved by at least $10 \%$ and sufficient to increase the FCM yield, in non isogenic commercial hybrids. The availability of bm 3 hybrids on the seed market in the USA has proved the feasibility of the bm 3 process for cell wall digestibility improvement of commercial hybrids, at least for late or medium late hybrids. But the higher seed costs of bm 3 commercial hybrids in the USA, their lower yield, and their higher intake in cattle, makes the economic interest of such hybrids still unclear. In Europe, the results obtained until now with early or medium early bm 3 hybrids have not made it possible to draw any definite conclusion. The reputation of bm 3 genotypes is poor, and they are still suspected of great susceptibility to lodging, on top of their lower yields. Nevertheless in INRA Lusignan, an experimental medium early bm3 hybrid was bred with a yield close to $14 \mathrm{t} \cdot \mathrm{ha}^{-1}$, a NDFD close to $59 \%$, and an acceptable standability, when normal hybrids of similar earliness yielding about $18 \mathrm{t} \cdot \mathrm{ha}^{-1} \mathrm{had} \mathrm{a}$ NDFD equal or lower than $47 \%$. However it may be, the breeding effort of bm 3 lines was until now very low. The choice of using lower yielding hybrids of higher feeding value, such as bm 3 hybrids, is a matter of strategy which has yet to be agreed on, and especially so in more friendly environmental conditions of plant cropping and cattle rearing [25]. The search of COMT alleles, with less drastic effects than that of the bm 3, is also very likely an efficient way of improving cell wall digestibility in maize (or in any forage plant).

\section{GENETIC RESOURCES AND STRATEGIES FOR CELL WALL DIGESTIBILITY IMPROVEMENT}

\subsection{Improvement of cell wall digestibility by the use of specialty maize}

Different types of specialty maize hybrids (excluding here brown midrib hybrids) were investigated, mostly in North America, and different results were reviewed by Coors et al. [72]. Comparisons between multi-tillering and non tillering maize for feeding value traits were mostly investigated in Canada, but no clear difference in nutritive value was found $[72,98]$. Dwarf genotypes were also considered for cattle feeding many years ago, when the role of grain in silage maize feeding value was overestimated, because dwarf genotypes potentially increased the grain to stover ratio ([50, 154] cited in [72]). Akay and Jackson [5] compared normal, "NutriDense" and waxy maize hybrids given to cows as silage and grain. DM intake, milk and FCM yields were higher for cows fed the waxy diet. But, because hybrids were not isogenic, it was not possible to conclude on the greater efficiency of one particular maize. In an IE/ARPEB [119] experiment, a slightly higher FCM yield was observed in animals fed the waxy hybrids, compared to their isogenics. The lower milk yield was assumed to be related to a higher ruminal acidity in animals fed normal hybrids, that probably led to a decrease of cell wall digestion. Kuehn et al. [128], Bal et al. [20], Thomas et al. [169], and Clark et al. [67] compared grain or dual type hybrids, and leafy type hybrids. In the two first papers, DM intake, milk yield and milk components did not differ for cows fed 
the grain or the leafy hybrid. In the two last papers, cows fed the diet with the leafy maize silage produced higher yields of milk, FCM, and milk protein, than cows that were fed the diet with the normal maize silage. The leafy hybrid was also more digestible in vitro. However, in these two experiments, normal and leafy hybrids were not isogenic, and the higher milk yield cannot be surely related to the leafy trait. Bal et al. [21] did not find any difference in NDF in situ disappearance between a grain and a leafy hybrid. In the measurements performed in Lusignan [24], two leafy hybrids had NDFD similar to values observed in hybrids of rather low cell wall digestibility. Lax leaf inbreds had lignin concentration nearly equal to those of the low lignin bm3 mutant, and they should be of interest for cattle feeding. But no functional relationships appeared between the lax leaf phenotype and the digestibility or the lignin content [96]. The occurrence of the lax leaf phenotype and the low lignin concentration in the same early-generation inbred family was considered as a "fortuitous random combination of traits". No specialty maize has so far appeared of great interest for silage use, except brown midrib types (mostly bm3).

\subsection{Drift of cell wall digestibility in maize, and necessity of renewing genetic resources}

Tremendous improvements in maize yield, yield regularity, stalk standability, stalk rot resistance and stay-green have been achieved in the last five decades in Europe $[32,86]$, and in the last century in the USA [161, 175, 176]. In forage maize [29], the genetic progress was found to be close to $0.17 \mathrm{t} \cdot \mathrm{ha}^{-1}$.year ${ }^{-1}$ for hybrids registered from whole plant experiments in France between 1986 (the first year with registration after forage maize official trials) and 2000. In the period before 1986, whole plant genetic progress was less important in hybrids bred for grain yield, as Inra258 registered in 1958 yielded about $12 \mathrm{t} \cdot \mathrm{ha}^{-1}$, LG11 registered in $197013 \mathrm{t} \cdot \mathrm{ha}^{-1}$, Dea registered in $198015 \mathrm{t} \cdot \mathrm{ha}^{-1}$, but Anjou285 and Nexxos registered in 1994 and 2000 yielded 18 and $20 \mathrm{t} \cdot \mathrm{ha}^{-1}$, respectively $[29,32]$. However, feeding value was not considered for forage maize registration until 1998, and a significant drift of hybrids towards lower in vivo digestibility values was observed in the last two or three decades (Tab. VII; and [27, 30]). European hybrids of the 1960-70 era had a higher OMD and NDFD than hybrids

Table VII. In vivo genetic variation for OMD and NDFD in early maize hybrids registered in France, separated in two different eras of breeding, 1958-1988 and 1989-2000 (INRA Lusignan unpublished data).

\begin{tabular}{lcccc}
\hline & $\begin{array}{c}\text { Hybrid } \\
\text { number }\end{array}$ & Mean & Mini & Maxi \\
\hline Early registered hybrids & 220 & 70.0 & 65.3 & 74.3 \\
OMD & & 48.3 & 39.4 & 58.4 \\
NDFD & 65 & & & \\
Registered 1958-1988 & & 70.7 & 66.3 & 73.7 \\
OMD & 155 & 50.0 & 41.0 & 58.4 \\
NDFD & & 69.7 & 65.3 & \\
Registered 1989-2000 & & 47.6 & 39.4 & 54.3 \\
OMD & & & & \\
NDFD & & &
\end{tabular}

For abbreviations, see Table I. 
registered since than. Statistical computation proved that the most important switch occurred in 1989 [27]. Hybrids with a low cell wall digestibility were more numerous after 1989 than hybrids previously registered. When compared to the well-known early hybrid Fanion (NDFD = 51.0\%), 40\% of early hybrids registered before 1989 had a higher cell wall digestibility than Fanion, but this was only $15 \%$ of the hybrids registered in and after 1989. The cell wall digestibility upper values of hybrids registered in the past decade were also lower than those of hybrids registered before 1989 , even if a few modern hybrids had a good cell wall digestibility. In the USA, Lauer et al. [133] highlighted an annual rate of forage yield increase of 0.13 to $0.16 \mathrm{t} \cdot \mathrm{ha}^{-1}$ since 1930 . But they did not find any change of the in vitro digestibility of the whole plant, nor of the cell wall digestibility, whereas major improvement in stalk standability, and in stalk rot resistance, were achieved during the same period. The discrepancy between European and US results could be due to a different evolution of hybrid germplasm in Europe and in the USA. Dent lines in modern European hybrids are now more related to Iodent and Reid origins than were old early dent lines used in Europe, with higher cell wall digestibility. Old European flint lines of high cell wall digestibility such as F7 are not involved in the modern flint germplasm, due to their low combining ability values for yield, stalk rot or lodging resistance. Some modern early European hybrids are also dent or quasi-dent hybrids. It seems likely that the maize improvement in the US was carried without major germplasm changes, and continuously based on the Reid and Lancaster groups. Moreover, in Lundvall et al. [136], no trend towards higher or lower values has been evidenced in stem IVNDFD, or in stem ADL/NDF content, between lines of early cycles of breeding in BSSS such as B14 or B37, and lines of advanced cycles such as B89 or B94. No difference was shown between lines B73 (BS13C5) and B84
(BS13C7). The observed drift of maize towards lower feeding values in Europe, and similarly the necessity to improve feeding value of late hybrids, highlighted the need to investigate renewed and specific genetic resources. Significant improvement of maize cell wall digestibility in the USA or in Europe will be based on targeted introduction of original germplasm in currently used elite germplasm.

\subsection{Investigating genetic resources for cell wall digestibility improvement}

Today, among maize hybrids registered in France, hybrids with the highest NDFD values are 6 percent points higher than the average value of hybrids of similar earliness, but they are 10 percent points lower than the best bm3 hybrid. Most parental lines currently used in commercial hybrids are of medium or weak cell wall digestibility. In Argillier et al. [14], a great range of cell wall digestibility was found in a set of 125 normal maize lines of various origins (mostly early or medium-early, but including some medium-late). The DINAG value ranged between 53.0 and $64.5 \%$, and $68.7 \%$ including bm 3 lines. As also established by Méchin et al. [139, 140], few normal lines such as F4 had a DINAG equal to the DINAG of some bm3 lines. But, most of early and medium early hybrids are crosses between Iodent or Reid related dent lines and early flint lines related to F2, both with poor DINAG ranging between 56.6 and $58.2 \%$. Lines of superior feeding value, which are indeed available, are not used as parents in elite varieties, partly because they lead to poor-yielding hybrids (lower additive value, and lower heterotic pattern) and partly because their hybrid progenies are susceptible to lodging. But there is no evidence of an absolute or definite linkage between these poor agronomic traits and the feeding value. The correlation between yield and NDFD was only -0.38 (without bm3 hybrids, INRA Lusignan unpublished 
data). Moreover, Argillier [10] proved the independence between lodging susceptibility and DINAG.

Breeding for higher cell wall digestibility indeed demands to have a large investigation in maize genetic resources, either lines or ecotypes (and similarly in any other forage crop). The germplasm investigated until now for cell wall digestibility measurements only represents a small part of the available genetic resources in maize, and is mostly based on lines currently or quite recently used in grain maize breeding. The old lines bred from the early selfing in the different maize populations, and their progenies obtained during the early cycles of breeding, had to be investigated systematically for cell wall digestibility traits. The objective is to discover lines that were considered not suitable for grain breeding, and then forgotten for silage maize breeding. Similarly, cell wall digestibility has also to be investigated in ecotypes from which no lines were developed. Because there is obviously a great gap in agronomic value between these old lines and elite modern lines, specific strategies of introgressing feeding value traits in elite germplasm have to be considered.

\subsection{Investigating QTL and allelic variation for cell wall digestibility improvement}

Once lines of different feeding values and different genetic background are identified, different RIL progenies should be developed in order to determine the genomic location involved in feeding value traits. In two RIL progenies, Méchin et al. [141] and Roussel et al. [160] found three major clusters for cell wall digestibility and lignification traits, located in descending order for both LOD values and percentage of explained phenotypic variation in bins 6.06, 3.05/06, and 9.02. The bin 6.06, which gathered together 11 individual QTL, was also greatly involved in cell wall carbohydrate composition because QTL for hemicellulose and cellulose contents (as percentage of NDF) were also found at this location. Three other clusters were also involved in cell wall digestibility and lignification traits, located in bins $2.08,4.08$, and 6.01. The identification of the underlying genes will be achieve in diverse ways including colocalization with known candidate genes, cDNA or EST mapping, and $\mathrm{BAC}$ sequencing. Once genes are identified, the choice of favorable alleles could be carried out through allele sequencing in a collection of lines, followed by the study of the linkage disequilibrium between the nucleotide polymorphism (SNP, single nucleotide polymorphism, or INDEL, insertion deletion polymorphism) in alleles, and the cell wall digestibility in lines. This strategy also allowed a heavily targeted possibility of marker assisted selection (MAS), with a very small modification of the backcrossed elite lines.

The different structural or regulatory genes of the lignin pathway could also be subjected to a SNP analysis, whether or not QTL have been found close to these genes, with a correlative study of the cell wall digestibility in the different lines. Such investigations are in progress in maize within the Génoplante network. Allelic variation in CCoAOMT1 and CCoAOMT2 genes (caffeoyl CoA O-methyl transferase, both sequenced by Civardi et al. [66]), and COMT gene (sequenced by Collazo et al. [68]) was analyzed in a set of 28 maize lines chosen for their variable levels of digestibility and the large diversity of their genetic origins. As observed in other known CCOAOMT genes, the sequence of the CCOAOMT1 gene contained four introns. However, the fourth intron was missing in the CCoAOMT2 gene. The CCoAOMT1 gene was well-conserved among lines, and its polymorphism was not associated with DINAGZ digestibility values. At present, this gene did not appear as a priority target in cell wall digestibility improvement. 
Polymorphism of CCoAOMT2 genomic sequences was essentially located in introns. However, one SNP, located in the first intron, explained $30 \%$ of the observed DINAGZ variation $(P=0.0026)$, and three other SNP also appeared to be significantly related to DINAGZ. Moreover, using the RIL progeny described in Roussel et al. [160], the CCoAOMT2 gene was mapped on chromosome 9, in bin 9.02, and thereby colocalizing with a QTL involved in the DINAGZ, ADL/NDF and KL/NDF variation. The first exon of CCOAOMT2 of one early flint European line, which had a high digestibility and a high $\mathrm{S} / \mathrm{G}$ ratio, appeared also deeply modified, differing greatly at the $\mathrm{N}$ terminal region. Among CCoAOMT1, CCoAOMT2, and COMT genes, the COMT gene was the most variable, not only with many SNP and INDEL in its unique intron, but also several variations in exons leading to several amino acid changes. Association studies between these allelic modifications and the cell wall digestibility have shown that one INDEL, located in the intron, explained $32 \%$ of the observed DINAGZ variation $(P=0.0017)$. When considering these results, results of Guillet et al. [109], and unpublished Génoplante data on maize genes, a high degree of nucleotide polymorphism seemed present in maize genes of the lignin pathway. Feeding value of elite maize lines should be greatly improved by studying allelic variation through high throughput SNP genotyping, in conjunction with the measurement of cell wall digestibility in very large collection of lines, including old lines and ecotypes, followed by a MAS targeted introgression of alleles or genomic areas linked to the favorable SNP.

\subsection{Genetic engineering of resources for cell wall digestibility improvement}

Another relevant way in breeding forage crops of higher digestibility is to devise specific genetic resources through genetic engineering in the lignin pathway. Boudet [46], Dixon et al. [88], and Chen et al. [58] for woody plants, have recently published extensive reviews of genetic engineering of the lignin pathway, and the resulting consequences on lignin content and structure of altered transgenic plants. Highly variable results have often been observed regardless of the transformation method. However, these inconsistencies have highlighted the necessity "to re-evaluate how we have come to arrive at the current metabolic grid model for the monolignol biosynthesis" [88]. Data related to cell wall digestibility were only provided in a part of the papers reviewed by Dixon et al. [88] or in later published works $[40-42,104,110,150$, $153,163]$. Very few results have been published on maize and in general on monocotyledons [150]. However, whatever the plant species, and whatever the enzyme downregulated in the lignin pathway, an increase in cell wall digestibility ranging from 9 to $90 \%$ was observed in all experiments, except inconsistencies between glasshouse and field results in Baucher et al. [40], with heterogeneous effects on cell wall phenolics. Nevertheless, these results clearly established the efficiency of antisense or silencing strategies in increasing the cell wall digestibility of plants.

According to opinions of Halpin et al. [112] and Casler and Kaeppler [54], the alteration of early steps in phenylpropanoid metabolism (PAL, phenylalanine ammonia-lyase; $\mathrm{C} 4 \mathrm{H}$, cinnamate 4-hydroxylase), which are clearly involved in other important processes in plants, could lead to too many adverse pleiotropic effects to be useful for cell wall digestibility improvement of plants. CCR (cinnamoyl CoA reductase) and CAD (cinnamyl alcohol dehydrogenase), that "function after all possible branch points in the pathway", were then considered as potentially suitable targets [112]. Downregulated CAD plants had no or slight changes in lignin content, but some of 
these plants had a higher cell wall digestibility $[40,41]$. The recent discovery of a SAD (sinapyl alcohol dehydrogenase) in aspen [134] also opens new possibilities in cell wall engineering. But, according to literature data, the maize bm1 mutant proved to be not very efficient in cattle feeding. Therefore CAD (and perhaps) SAD are probably better targets for paper pulping in dicotyledons than for forage digestibility improvement in monocotyledons. Similarly, before concluding on the relevance of CCR engineering for forage improvement, it is necessary to further elucidate further the possible specificity of different CCR, and the independence of pathways leading to guaiacyl and syringyl units. Moreover, plants could show important growth defects when CCR activity is very low [149].

Based on current knowledge of the lignin pathway [88, 117], CCoAOMT is (are) probably a major hub in controlling lignification and digestibility, and therefore a preferential target for digestibility improvement. Up to now, only the work of Guo et al. [110] has illustrated the efficiency of a CCOAOMT down-regulation in digestibility improvement. Alfalfa plants with a 5\% residual CCoAOMT activity had an increased cell wall digestibility of $34 \%$. No changes were observed in ADL content, whereas KL content was reduced by $25 \%$. The bm 3 maize is thus far the best model available for improving digestibility through endogenous enzyme silencing, and COMT (caffeic acid O-methyltransferase) and $\mathrm{F} 5 \mathrm{H}$ (ferulate 5-hydroxylase) are also probably key targets in forage digestibility improvement. This hypothesis is also strengthened by converging results indicating that COMT, in maize and in vivo, is very likely to be a 5-hydroxyconiferaldehyde O-methyltransferase (AldOMT or CaldOMT) rather than a caffeic acid O-methyltransferase [31]. Among data published on COMT down-regulation (review in $[88,150]$ ), the greatest improvement in cell wall digestibility was observed in tobacco in which both a decrease in lignin content and an unexpected increase in $\mathrm{S} / \mathrm{G}$ ratio were observed [163]. Piquemal et al. [150] reported only recently one COMT down-regulation in maize, despite the fact the bm 3 mutant and the COMT gene were known for years. In plants with $30 \%$ COMT residual activity, they observed a 9 percent point increase in maize cell wall digestibility [150]. This increase in cell wall digestibility was similar to those observed in the bm 3 isogenic lines. The drawback of COMT down-regulation or silencing is the correlative $\mathrm{S} / \mathrm{G}$ decrease, because a higher $\mathrm{S} / \mathrm{G}$ ratio could impact positively the cell wall digestibility in maize [140]. CCoAOMT could be considered a priori as an even better target than COMT, because CCoAOMT down-regulation in plants would logically result in a lower lignin content without a decrease in $\mathrm{S} / \mathrm{G}$ ratio [110]. At present, data are not yet available concerning the respective roles or tissue specificity of the different CCoAOMT genes in maize and other forage crops. In poplar, CCoAOMT genes exhibited precise cell-specific expression patterns [57].

The polymerisation reactions may also be considered as good targets, even though laccases and peroxydases are encoded by multigene families. Ros Barcelo ([159] quoted in [155]) postulated that peroxydases were the sole enzymes involved in the ultimate step of lignin biosynthesis, but most recent reports considered the involvement of both laccases and peroxydases in the formation of phenoxy radicals $[46,155]$. Up to now, mechanisms of phenoxy radical coupling of monolignols are still unknown, and no clear-cut results have been provided to determine if lignin results from random free-radical coupling or from dirigent protein orchestrated polymerization [46].

In grasses, enzymes involved in (i) pcoumaric and ferulic acid biosynthesis; (ii) their transport to the cell wall; (iii) their coupling to carbohydrates and cell wall 
polymers, could very likely be relevant targets for plant engineering. Ranocha et al. [155] established that the down-regulation of one laccase in poplar led to plants exhibiting no visible phenotype, but with highly altered xylem fiber cell walls and mechanical properties of the wood. These plants were not modified in lignin content, nor in $\mathrm{S} / \mathrm{G}$ ratio, but accumulated soluble phenolics. The authors speculated that such a laccase was involved in the formation of certain types of phenoxy radicals leading to cross-linking of xylem fibers. It could also be hypothesized that such plants could be easier to break down by ruminating cattle, and then of higher ingestibility. Laccase down-regulated plants could therefore be considered as resources of reduced crosslinked fibers, and should be considered as potential targets in forage digestibility and ingestibility improvement.

Regulatory genes of lignification could be hypothesized as potential targets for cell wall digestibility improvement in plants. Myb-related transcription factors are involved in regulating phenylpropanoid metabolism, and Tamagone et al. [168] proved that lignin content was heavily reduced in mature parts of tobacco plants overexpressing an Antirrhinum Myb factor. No measurements of digestibility were given in this paper. Moreover, Myb genes in maize belong to a very large family of expressed regulatory proteins [152]. Although identification of $\mathrm{Myb}$ factors specifically involved in the lignin pathway is necessary before using them for cell wall digestibility improvement, the modification of such regulatory genes could allow the control of the entire, or at least a part, of the pathway in given tissues [108]. The overall rate of lignin deposition in the cell wall is regulated by monolignol synthesis, but also by the transport of their precursors to the cell wall. Transport forms have not been clarified so far, but 4-O- $\beta$-Dglucosides, presumably synthesized by UDPG-utilizing glucosyltransferases and subsequently hydrolyzed by monolignols specific $\beta$-glucosides, are the most probable candidates [108], and are indeed targets for plant engineering in cell wall digestibility improvement.

The simultaneous down-regulation of two (or more) genes could be more efficient than the down-regulation of only individual genes. Tobacco hybrids resulting from the crossing of transgenic lines down-regulated for CCR and CAD, CCR and COMT, or COMT and CAD, had a reduced lignin content, but with no adverse impact on the growth of the plants $[1,56,148]$. Moreover, from results of Abbott et al. [1], chimeric silencing constructs could also be more efficient than achieving multiple suppressions by crossing independent events. This strategy should allow a synergetic enzyme reduction that regulates the flux of metabolites through the lignin pathway. Moreover, the optimal construct could be designed to reduce the expression of one gene while increasing the expression of another. For example, the simultaneous down-regulation of CCOAOMT and over-expression of $\mathrm{F} 5 \mathrm{H}$ could be hypothesized as a first step in a forage ideotype building, assuming that this ideotype should logically have a reduced lignin content with an increased S/G ratio.

Up until now, data on cell wall composition and digestibility in transformants and in naturally occurring mutants, were often difficult to predict. In maize, more data will be necessary concerning both the lignin pathway and suitable promoters to drive transgene expression. Comparison of antisense data with data obtained in knocked-out mutants will also be of interest, especially for genes belonging to multigenic families. Moreover, little data are currently available on the stability of transgene expression throughout generation of selfing, crossing, and successive backcrossing in elite germplasm. Feeding value tests in cattle (with sheep in digestibility crates and/or with milking cows) will 
then be necessary to reinforce the relevance of this new technology in cattle feeding. Moreover, a complete knowledge of the consequences of the genetic engineering appeared all the more important that unexpected increase in lignin content was observed in Bt11 and Mon810 maize tolerant to the European corn borer [162].

\section{CONCLUSION}

In the search for a forage ideotype, the breeding effort to be placed respectively on either biomass yield or biomass digestibility is open to debate. A high digestibility should allow farmers to provide less concentrates to cattle, and is a necessity for good forage intake. For a given quantity of inputs (nitrogen fertilization, ...), and water availability, a forage ideotype resembling bm3 maize would maximize the production of energy having great ingestibility and digestibility in cattle, and it could increase the profit in cattle productions.

Cell wall digestibility is undoubtedly one of the major targets for the improvement of forage feeding value. A higher cell wall digestibility would lead to both a higher overall digestibility and ingestibility. Because lignin content is not the only trait involved in cell wall digestibility, breeders should use a trait directly related to cell wall digestibility, such as IVNDFD or DINAGZ. A large scale investigation of genetic resources, including germplasm forgotten after decades of breeding for agronomic value and/or grain yield, is required. Comprehensive knowledge of the lignin pathway and cell wall biogenesis will allow plant breeders to choose the best targets for the improvement of plant digestibility. That said, most of the lignification research has been done on dicotyledons and woody plants, and grass breeders should keep in mind the specificity of grass cell walls.
The improvement of forage cell wall digestibility may be envisaged both through genetic engineering or marker assisted introgression of favorable alleles. It may be possible to improve similarly cell wall digestibility with a targeted use of natural genetic resources and genetic engineering. However, with a transgene strategy, only one parental line needs to be backcrossed, because of the dominant behavior of engineered genes, but the stability of transgene expression over generations is still unknown. Favorable alleles will probably have partially recessive behavior, but different favorable alleles could be introgressed in different heterotic groups, allowing the breeding of hybrids with the best combination of alleles and epistatic interactions between these alleles and others genes related to lignification or digestibility.

Maize may be considered as a model plant for lignification and digestibility studies in monocotyledons. At present, similar research efforts are not being made on other annual or perennial grass forage plants. Because of the synteny between rice and maize [182], the availability of the rice genome will bring very valuable complementary information, even if the lignin pathway is seemingly not investigated in rice. Moreover, gene mining and genetic engineering in model plant and systems (Arabidopsis, Zinnia, ...) are also complementary approaches for improvement of cell wall digestibility in monocotyledon forage crops. Finally, results obtained in maize could also be exploited for dicotyledons forage improvement, despite the specificity of monocotyledon lignification.

\section{ACKNOWLEDGEMENTS}

Special thanks to J. De Boever (Gent, Belgium) and P. Tillmann (Kassel, Germany) for giving their valuable unpublished information on the relationships between traits related to silage maize feeding value. Thanks also to 
J. Ralph (Madison, USA) who suggested us to write this synthesis, even if the foreseen related project was cancelled. Thanks to the maize breeding companies involved in the ProMaïs INRA network "DINAG" that contributes to the funding of the forage maize research in Lusignan. Thanks to an anonymous reviewer for his greatly fruitful criticisms.

\section{REFERENCES}

[1] Abbot J.C., Brakate A., Pinçon G., Legrand M., Lapierre C., Mila I., Schuch W., Halpin C., Simultaneous suppression of multiple genes by single transgenes. Down-regulation of three unrelated lignin biosynthetic genes in tobacco, Plant Physiol. 128 (2002) 844-853.

[2] Abou-el-Enin O.H., Fadel J.G., Mackill D.J., Differences in chemical composition and fibre digestion of rice straw with, and without, anhydrous ammonia from 53 rice varieties, Anim. Feed Sci. Technol. 79 (1999)129-136.

[3] Aerts J.V., de Boever J.L., Cottyn B.G., de Brabander D.L., Buysse F.X., Comparative digestibility of feedstuffs by sheep and cows, Anim. Feed Sci. Technol. 12 (1984) 47-56.

[4] Agbagla-Dohnani A., Nozière P., Clément G., Doreau M., In sacco degradability, chemical and morphological composition of 15 varieties of European rice straw, Anim. Feed Sci. Technol. 94 (2001) 15-27.

[5] Akay V., Jackson J.A. Jr., Effects of NutriDense and waxy corn hybrids on the rumen fermentation, digestibility and lactational performance of dairy cows, J. Dairy Sci. 84 (2001) 1698-1706.

[6] Akin D.E., Rigsby L.L., Hanna W.W., Gates R.N., Structure and digestibility of tissues in normal and brown midrib pearl millet (Pennisetum glaucum), J. Sci. Food Agric. 56 (1991) 523-538.

[7] Andrieu J., Demarquilly C., Valeur alimentaire du maïs fourrage. II. Influence du stade de végétation, de la variété, du peuplement, de l'enrichissement en épis et de l'addition d'urée sur la digestibilité et l'ingestibilité du maïs fourrage, Ann. Zootech. 23 (1974) 1-25.

[8] Andrieu J., Demarquilly C., Valeur nutritive des fourrages, tables et prévisions, in: Jarrige R. (Ed.), Alimentation des bovins, ovins et caprins, INRA Éditions, Paris, 1988, pp. 351-471.

[9] Andrieu J., Demarquilly C., Dardenne P., Barrière Y., Lila M., Maupetit P., Rivière F., Femenias N., Composition and nutritive value of whole maize plant fed fresh to sheep. I. Factors of variation, Ann. Zootech. 42 (1993) 221-249.
[10] Argillier O., Relations entre verses, valeur alimentaire et productivité chez le maïs fourrage, Thèse, INA PG, 1995,173 p.

[11] Argillier O., Barrière Y., Hébert Y., Genetic variation and selection criteria for digestibility traits of forage maize, Euphytica 82 (1995) 175-184.

[12] Argillier O., Barrière Y., Traineau R., Emile J.C., Hébert Y., Genotype $\times$ environment interactions for digestibility traits in silage maize estimated from in vivo measurements with standards sheep, Plant Breed. 116 (1997) 423-427.

[13] Argillier O., Barrière Y., Dardenne P., Emile J.C., Hébert Y., Genotypic variability for in vitro criteria and relationships with in vivo digestibility in forage maize hybrids, Plant Breed. 117 (1998) 437-441.

[14] Argillier O., Méchin V., Barrière Y., Synthèse des travaux du groupe de travail Inra - ProMaïs dinag2, Micellaneous paper INRA, 1999, 30 p.

[15] Argillier O., MéchinV., Barrière Y., Genetic variation, selection criteria and utility of inbred line per se evaluation in hybrid breeding for digestibility related traits in forage maize, Crop Sci. 40 (2000) 1596-1600.

[16] Aufrère J., Étude de la prévision de la digestibilité des fourrages par une méthode enzymatique, Ann. Zootech. 31 (1982) 111-130.

[17] Aufrère J., Michalet-Doreau B., In vivo digestibility and prediction of digestibility of some by-products, EEC seminar, Melle Gontrode, Belgium, 26-29 September, 1983.

[18] Aydin G., Grant R.J., O’Rear J., Brown midrib sorghum in diets of lactating dairy cows, J. Dairy Sci. 82 (1999) 2127-2135.

[19] Baker S.K., Klein L., Minsin D.J., Purser D.B., Voluntary intake and the energy required to shear or comminute dry, mature subterranean clover, in: Proceedings of the Nutrition Society Abstr., 1992, pp. 17-74.

[20] Bal M.A., Shaver R.D., Al-Jobeile H., Coors J.G., Lauer J.G., Corn silage hybrid effects on intake, digestion, and milk production by dairy cows, J. Dairy Sci. 83 (2000) 2849-2858.

[21] Bal M.A., Shaver R.D., Skinners K.J., Coors J.G., Lauer J.G., Straub R.J., Koegel R.G., Stage of maturity, processing, and hybrid effects on ruminal in situ disappearance of whole-plant corn silage, Anim. Feed Sci. Technol. 86 (2000) 83-94.

[22] Ballard C.S., Thomas E.D, Tsang D.S., Mandevu P., Sniffen C.J., Endres M.I., Carter M.P., Effect of corn silage hybrid on dry matter yield, nutrient composition, in vitro digestion, intake by dairy heifers, and milk production by dairy cows, J. Dairy Sci. 84 (2001) 442-452.

[23] Barnes R.F., Muller L.D., Bauman L.F., Colenbrander V.F., In vitro dry-matter disappearance of brown midrib mutants, J. Anim. Sci. 33 (1971) 881-884. 
[24] Barrière Y., Synthèse des travaux du groupe de travail Inra - ProMaïs dinag3, Micellaneous paper INRA (2001) $17 \mathrm{p}$.

[25] Barrière Y., Le maïs et l'eau, une situation aujourd'hui paradoxale, mais des progrès génétiques à attendre d'un idéotype redéfini, Fourrages 168 (2001) 477-489.

[26] Barrière Y., Argillier O., Brown-midrib mutants of maize, a review, Agronomie 13 (1993) 865-876.

[27] Barrière Y., Argillier O., In vivo silage feeding value of early maize hybrids released in France between 1958 and 1994, Euphytica 99 (1997) 175-182.

[28] BarrièreY., Emile J.C., Effet des teneurs en grain et de la variabilité génétique sur la valeur énergétique du maïs-ensilage mesurée par des vaches laitières, Agronomie 10 (1990) 201-212.

[29] Barrière Y., Emile J.C., Le maïs fourrage. II. Évaluation et perspectives de progrès génétique sur les caractères de valeur agronomique, Fourrages 163 (2000) 209-220.

[30] Barrière Y., Emile J.C., Le maïs fourrage. III. Évaluation et perspectives de progrès génétique sur les caractères de valeur alimentaire, Fourrages 163 (2000) 221-238.

[31] Barrière Y., Guillet C., The maize bm3 mutation most probably occurs in the gene encoding 5-hydroxyconiferyl aldehyde O-methytransferase (AldOMT) rather than in the gene encoding caffeic acid O-methyltransferase, 9th international cell wall meeting, Toulouse, 2-7 September 2001, p. 161 .

[32] Barrière Y., Gallais A., Derieux M., Panouillé A., Étude de la valeur agronomique en plante entière au stade de récolte ensilage de différentes variétés de maïs grain sélectionnées entre 1950 et 1980, Agronomie 7 (1987) 73-79.

[33] Barrière Y., Traineau R., Emile J.C., Hébert Y., Variation and covariation of silage maize digestibility estimated from digestion trials with sheep, Euphytica 59 (1992) 61-72.

[34] Barrière Y., Argillier O., Chabbert B., Tollier M.T., Monties B., Breeding silage maize with brown-midrib genes. Feeding value and biochemical characteristics, Agronomie 14 (1994) $15-25$.

[35] Barrière Y., Emile J.C., Traineau R., Hébert Y., Genetic variation in the feeding efficiency of maize genotypes evaluated from experiments with dairy cows, Plant Breed. 114 (1995) 144-148.

[36] Barrière Y., Emile J.C., Hébert Y., Genetic variation in the feeding efficiency of maize genotypes evaluated from experiments with fattening bulls, Agronomie 15 (1995) 539-546.

[37] Barrière Y., Argillier O., Michalet-Doreau B., Hébert Y., Guingo E., Giauffret C., Emile J.C., Relevant traits, genetic variation and breeding strategies in early silage maize, Agronomie 17 (1997) 395-411.

[38] Barrière Y., Tovar-Gomez M.R., Emile J.C., Sauvant D., Genetic variation in rate and extent of the in situ cell wall degradation of maize stalks at silage harvest time, Agronomie 18 (1998) 581-589.

[39] Barrière Y., Argillier O., Méchin V., In vivo digestibility and biomass yield in normal and bm3 hybrids made from crossing between early and medium late lines of maize, Maydica 43 (1998) 131-136.

[40] Baucher M., Bernard-Vailhé M.A., Chabbert B., Besle J.M., Opsomer C., Van Montagu M., Botterman J., Down-regulation of cinnamyl alcohol dehydrogenase in transgenic alfalfa (Medicago sativa L.) and the effect on lignin composition and digestibility, Plant Mol. Biol. (1999) 437-447.

[41] Bernard-Vailhé M.A., Influence de la qualité des lignines et acides phénols sur la dégradation des parois végétales dans le rumen - Étude de plantes transgéniques et normales, Thèse, Université Blaise Pascal, Clermont-Ferrand, 1996, 226 p.

[42] Bernard-Vailhé M.A., Migné C., Cornu A., Maillot M.P., Grenet E., Besle J.M., Atanassova R., Martz F., Legrand M., Effect of modification of the o-Methyltransferase activity on cell wall composition, ultrastructure and degradability of transgenic tobacco, J. Sci. Food Agric. (1996) 385-391.

[43] Biston R., Dardenne P., Demarquilly C., Determination of forage in vivo digestibility by NIRS, in: XVI International Grassland congress, Nice, France, 1989, pp. 895-896.

[44] Blaxter K.L., Wainman F.W., Wilson R.S., The regulation of food intake by sheep, Anim. Prod. 3 (1961) 51-61.

[45] Block E., Muller L.D., Griel L.C., Garwood J.R., Garwood D.L., Brown-midrib3 corn silage and heat-extruded soybeans for early lactating dairy cows, J. Dairy Sci. 64 (1981) 1813-1825.

[46] Boudet A.M., Lignin and lignification: selected issues, Plant Physiol. Biochem. 38 (2000) 81-96.

[47] Bradshaw J.E., Mackay G.R., Half-sib family selection for yield of digestible organic matter in kale (Brassica oleracea L.), Euphytica 34 (1985) 201-206.

[48] Burnham C.R., Brinks R.A., Linkage relations of a second brown-midrib gene (bm2) in maize, $\mathrm{J}$. Am. Soc. Agric. 24 (1932) 960-963.

[49] Burnham C.R., Maize genetics, Coop. Newslett. 21 (1947) 36.

[50] Byers J.H., Kendall K.A., Ormiston E.E., Feeding value of dwarf corn compared to corn and hybrid sorghum silages, J. Dairy Sci. 48 (1965) 203-205. 
[51] Capper B.S., Thomson E.F., Herbert F., Genetic variation in the feeding value of barley and wheat straw, in: Reed J.D., Capper B.S., Neate J.H. (Eds.), Plant breeding and the nutritive value of crop residues, Addis Abeba, International livestock for Africa, 1988, pp. 177-193.

[52] Capper B.S., Sage G., Hanson P.R., Adamson A.H., Influence of variety, row type and time of sowing on the morphology, chemical composition and in vitro digestibility of barley straw, J. Agric. Sci. 188 (1992) 165-173.

[53] Carpentier B., Haurez P., Brauschwig P., Haurez P., Joulie M., Valorisation par les jeunes bovins et les vaches laitières d'ensilages de maïs choisis pour leur digestibilité différente, Renc. Rech. Ruminants 2 (1995) 113-118.

[54] Casler M.D., Kaeppler H.F., Molecular breeding for herbage quality in forage crops, in: Spangenberg G. (Ed.), Molecular breeding of forage crops, 2001, pp. 175-188.

[55] Cervantes S.J.M., Amaranth (Amanranthus spp.) as a forage, in: Proceedings of 4th Natl Amaranth Symposium, Perspectives on production, processing and marketing, Minneapolis, MN, 23-25 August 1990, pp. 47-54.

[56] Chabannes M., Barakate A., Lapierre C., Martia J.M., Ralph J., Pean M., Danoun S., Halpin C., Grima-Pettenati J., Boudet A.M., Strong decrease in lignin content without alteration of plant developement is induced by simultaneous down-regulation of cinnamoyl CoA reductase (CCR) and cinnamyl alcohol deshydrogenase (CAD) in tobacco plants, Plant J. 28 (2001) 257-270.

[57] Chen C., Meyermans H., Burggraeve B., De Rycke R.M., Inoue K., De Vleesschauwer V., Steenackers M., Van Montagu M.C., Engler G.J., Boerjan W.A., Cell-specific and conditional expression of caffeoyl-coenzyme A-3-O methyltransferase in poplar, Plant Physiol. 123 (2000) 853-867.

[58] Chen C., Baucher M., Christensen J.H., Boerjan W., Biotechnology in tress: towards improved paper pulping by lignin engineering, Euphytica 118 (2001) 185-195.

[59] Chenost M., Fibrousness of forage, its determination and its relation to feeding value, in: Proc. X Inter. Grassl. Congr., Helsinki, Finland, 7-16 July 1966, pp. 406-411.

[60] Chenost M., Martin-Rosset W., Comparaison entre espèces (mouton, cheval, bovin) de la digestibilité et des quantités ingérées des fourrages verts, Ann. Zootech. 34 (1985) 291-312.

[61] Cherney J.H., Axtell J.D., Hassen M.M., Anliker K.S., Forage quality characterization of chemically induced brown-midrib mutant in pearl millet, Crop Sci. 28 (1988) 783-787.

[62] Cherney D.J.R., Patterson J.A., Johnson K.D., Digestibility and feeding value of pearl millet as influenced by the brown-midrib, low lignin trait, J. Anim. Sci. 68 (1990) 4345-1351.

[63] Cherney J.H., Cherney D.J.R., Akin D.E., Axtell J.D., Potential of brown-midrib low-lignin mutants for improving forage quality, Adv. Agron. 46 (1991) 157-198.

[64] Ciba-semences, Valorisation laitière d'une variété de maïs en ensilage, Synthesis of an experimentation conducted by the EDE of Vendée during 1988-89-90, 1990, $13 \mathrm{p}$.

[65] Ciba-semences, Comparaison de la valorisation par des vaches laitières de deux hybrides de maïs, Miscellaneous paper, 1995, 7 p.

[66] Civardi L., Rigau J., Puigdomenech P., Nucleotide sequence of two cDNAs coding for caffeoyl coenzyme A O-methyltransferase (CCoAOMT) and study of their expression in Zea mays, Plant Physiol. 120 (1999) 1206.

[67] Clark P.W., Kelm S., Endres M.I., Effect of feeding a corn hybrid selected for leafiness as silage or grain to lactating dairy cattle, J. Dairy Sci. 85 (2002) 607-612.

[68] Collazo P., Montoliu L., Puigdomenech P., Rigau J., Structure and expression of the lignin O-methyltransferase gene from Zea mays L., Plant Mol. Biol. 20 (1992) 857-867.

[69] Collenbrander V.L., Lechtenberg L.F, Bauman L.F., Muller L.D., Rhykerd C.L. Nutritive value of brown midrib corn silage, J. Anim. Sci. 35 (1972) 1113.

[70] Collenbrander V.L., Lechtenberg L.F, Bauman L.F., Digestibility and feeding value of brown midrib corn stover, J. Anim. Sci. 37 (1973) 294-295.

[71] Collenbrander V.L., Lechtenberg L.F., Bauman L.F., Feeding value of low lignin corn silage, J. Anim. Sci. Abstr. 41 (1975) 332-333.

[72] Coors J.G., Carter P.R., Hunter R.B., Silage corn, in: Hallauer A.R. (Ed.), Specialty Corns, CRC Press, London, 1994, pp. 305-340.

[73] Cox W.J., Cherney D.J.R., Influence of brown midrib, leafy and transgenic hybrids on corn forage production, Agron. J. 93 (2001) 790-796.

[74] Cox W.J., Cherney J.H., Cherney D.J.R., Pardee W.D., Forage quality and harvest index of corn hybrids under different growing conditions, Agron. J. 86 (1994) 277-282.

[75] Craig W.M., Hong B.J., Broderick G.A., Bula R.J., In vitro inoculum enriched with particles associated microorganisms for determining rates of fiber digestion and protein degradation, J. Dairy Sci. 67 (1984) 2902-2909.

[76] Cummings D.G., McCullough M.E., A comparison of the yield and quality of corn and sorghum silage, University of Georgia, College of agriculture experimental station, Res. Bull. 67 (1969) 5-19.

[77] De Boever J.L., Cottyn B.G., Andries J.I., Buysse F.X., Vanacker J.M., The use of cellulase 
technique to predict digestibility, metabolizable and net energy of forage, Anim. Feed Sci. Technol. 19 (1988) 247-260.

[78] De Boever J.L., Cottyn B.G., De Brabander D.L., Vanacker J.M., Boucqué C.V., Prediction of the feeding value of maize silages by chemical parameters, in vitro digestibility and NIRS, Anim. Feed Sci. Technol. 66 (1997) 211-222.

[79] De Boever J.L., Cottyn B.G., de Brabander D.L., Vanacker J.M., Boucqué C.V., Equations to predict digestibility and energy value of grass silages, maize silages, grass hays, compound feeds and raw materials for cattle, Nutr. Abstr. Rev., Ser. B, Livest. Feeds and Feeding 69 (1999) 836-850.

[80] Deinum B., Bakker J.J., Genetic differences in digestibility of forage maize hybrids, Neth. J. Agric. Sci. 29 (1981) 93-98.

[81] Deinum B., Steg A., Hof G., Measurement and prediction of digestibility of forage maize in the Netherlands, Anim. Feed Sci. Technol. 10 (1984) 301-313.

[82] Deinum B., Struik P.C., Improving the nutritive value of forage maize, in: Proceedings of the 13th congress maize and sorghum section of Eucarpia, Wageningen, The Netherlands, 9-12 September 1985, pp. 77-90.

[83] Demarquilly C., Valeur alimentaire du maïs fourrage. I. Composition chimique et digestibilité du maïs sur pied, Ann. Zootech. 18 (1969) 17-32.

[84] Demarquilly C., Weiss P., Liaisons entre les quantités de matière sèche de fourrage vert ingérées par les moutons et celles ingérées par les ovins, Ann. Zootech. 20 (1971) 119-134.

[85] Demarquilly C., Andrieu J., Composition chimique, digestibilité et ingestibilité des fourrages européens exploités en vert, Prod. Anim. 5 (1992) 213-221.

[86] Derieux M., Darrigand M., Gallais A., Barrière Y., Bloc Y., Montalant Y., Estimation du progrès génétique réalisé chez le maïs grain en France entre 1950 et 1985, Agronomie 7 (1987) 1-11.

[87] Dijkstra N.D., Becker W.R., Deverteerbaarheid en voederwaarde van verse en geënsileerde snijmais, Pudoc, Wageningen, Verslagen Landbouwkd. Onderz. 66.14 (1960) 48 p.

[88] Dixon R.A., Chen F., Guo D., Parvathi K., The biosynthesis of monolignols, a "metabolic grid", or independant pathways to guaiacyl and syringyl units, Phytochemistry 57 (2001) 1069-1084.

[89] Dolstra O., Medema J.H., An effective screening method for genetic improvement of cell-wall digestibility in forage maize, in: Proceedings of the 15 th congress maize and sorghum section of Eucarpia, Baden, Austria, June 4-8 1990, pp. 258-270.

[90] Dolstra O., Medema J.H., de Jong A.W., Genetic improvement of cell-wall digestibility in forage maize (Zea mays L.). I. Performance of inbred lines and related hybrids, Euphytica 65 (1993) 187-194

[91] Doyle P.T., Devendra C., Pearce G.R., Rice straw as a ruminant feed, Canberra, International development press (Ed.), 1986.

[92] Dulphy J.P., Jouany J.P., Martin-Rosset W., Thériez M., Aptitudes comparées de différentes espèces d'herbivores domestiques à ingérer et digérer des fourrages distribués à l'auge, Ann. Zootech. 43 (1994) 11-32.

[93] Emerson R.A., Cornell Univ. Agric. Exp. Stn., Memoir 180, 1935.

[94] Emile J.C., Traineau R., Giovanni R., Valeur alimentaire du colza fourrager, Fourrages 133 (1993) 97-108.

[95] Emile J.C., Barrière Y., Mauries M., Effects of maize and alfalfa genotypes on dairy cow performances, Ann. Zootech. 45 (1996) 17-27.

[96] Falkner L.K., Coors J.G., Ostrander B.M., Kaeppler S.M., Hatfield R.D., Lax leaf maize, cell wall composition and nutritional value, J. Sci. Food Agric. 80 (2000) 255-262.

[97] Frenchick G.E., Johnson D.G, Murphy J.M., Otterby D.E., Brown midrib corn silage in dairy cattle ration, J. Dairy Sci. 59 (1976) 2126-2129.

[98] Freyman S., Kaldy M.S., Bowden D.S., Wilson D.B., Nutritive potential of multitillering corn compared with non tillering corn for silage, Can. J. Plant Sci. 53 (1973) 129-130.

[99] Fritz J.O., Cantrell R.P., Lechtenberg V.L., Axtell J.D., Hertel J.M., Brown midrib mutants in sudangrass and grain sorghum, Crop Sci. 21 (1981) 706-709.

[100] Garnsworthy P.C., Stokes D.T., The nutritive value of wheat and oat silages ensiled on three cutting dates, J. Agric. Sci. (Camb.) 121 (1993) 233-240.

[101] Gentinetta E., Bertolini M., Rossi I., Lorenzoni C., Motto M., Effect of brown midrib-3 mutant on forage quality and yield in maize, J. Genet. Breed. 44 (1990) 21-26.

[102] Givens D.I., Cottyn B.G., Dewey P.J.S., Steg A., A comparison of the neutral detergent-cellulose method with others laboratory methods for predicting the digestibility in vivo of maize silages from three European countries, Anim. Feed Sci. Technol. 54 (1995) 655-664.

[103] Goering H.K., van Soest P.J., Forage fiber analysis (apparatus, reagents, procedures and some applications), Agric Handb 379, US Gov Print Office, Washington, DC, 1971.

[104] Goujon T., Ferret V., Mila I., Pollet B., Ruel K., Burlat V., Lapierre C., Barrière Y., Jouanin L., Effects of down-regulation of AtCCR1 gene in Arabidopsis thaliana on external phenotype, lignins, digestible properties and monolignols pathway genes expression, Planta (2003), in press. 
[105] Goujon T., Sibout R., Pollet B., Maba B., Nussaume L., Bechtold N., Lu F., Ralph J., Barrière Y., Lapierre C., Jouanin L., A new Arabidopsis thaliana mutant deficient in the expression of O-methyltransferase. 1. Impact on lignins and sinapoyl esters, Plant Mol. Biol. (2003), in press.

[106] Grand C., Parmentier P., Boudet A., Boudet A.M., Comparison of lignins and enzymes involved in lignificaton in normal and brown-midrib bm3 mutant corn seedlings, Physiol. Veg. 23 (1985) 905-911.

[107] Grant R.J., Haddad S.G., Moore K.J., Pederson J.F., Brown midrib sorghum silage for midlactation dairy cows, J. Dairy Sci. 78 (1995) 1970-1980.

[108] Grima Pettenati J., Goffner D., Lignin genetic engineering revisited, Plant Sci. 145 (1999) 51-65.

[109] Guillet C., Barraud S., Carret V., Barrière Y., Structural analysis of maize genes involved in lignin biosynthesis pathway, 9th international cell wall meeting, Toulouse, 2-7 September 2001, p. 166.

[110] Guo D., Chen F., Inoue K., Blount J.W., Dixon R.A., Downregulation of caffeic acid 3-O-methyltransferase and caffeoyl CoA 3-O-methyltransferase in transgenic alfalfa. Impacts on lignin structure and implications for the synthesis of G and S lignin, Plant Cell 13 (2001) 73-88.

[111] Gurrath P.A., Dhillon B.S., Pollmer W.G., Klein D., Zimmer E., Utility of inbred lines evaluation in hybrid breeding for yield and stover digestibility in forage maize, Maydica 36 (1991) 65-68.

[112] Halpin C., Foxon G.A., Fentem P.A., Transgenic plants with improved energy characteristics, in: Chesson A., Wallace R.J. (Eds.), Biotechnology in animal feeds and animal feeding, VCH Publishers, Weinheim, 1995, pp. 279-293.

[113] Halpin C., Holt K., Chojecki J., Olivier D., Chabbert B., Monties B., Edwards K., Barakate A., Foxon G.A., Brown-midrib maize (bm1), a mutation affecting the cinnamyl alcohol dehydrogenase gene, Plant J. 14 (1998) 545-553.

[114] Hancock T.W., Parker J.P., Hibberd C.A., Dicks M.R., Kenaf versus alfalfa hay for growing beef cattle, Anim. Sci. Res. Rep. (1993) 143-147.

[115] Hawkins G.E., Parr G.E., Little J.A., Composition, intake, digestibility and prediction of digestibility of coastal Bermudgrass hay, J. Dairy Sci. 47 (1964) 865-870.

[116] Hoden A., Barrière Y., Gallais A., Huguet L., Journet M., Mourguet M., Le maïs brownmidrib plante entière. III Utilisation sous forme d'ensilage par des vaches laitières, Bull. Tech. CRZV Theix 60 (1985) 43-58.
[117] Humphreys J.M., Chapple C., Rewriting the lignin roadmap, Cur. Opin. Plant Biol. 51 (2002) 224-229.

[118] Hunt C.W., Kezar W., Hinnam D.D., Combs J.J., Loesche J.A., Moen T., Effects of hybrids and ensiling with and without a microbial inoculant on the nutritional characteristics of whole-plant corn, J. Anim. Sci. 71 (1993) 39-43.

[119] IE/ARPEB, Maïs waxy à destination élevage pour les vaches laitières, Ognaos Flash, No. 34, Octobre 1993, 8 p.

[120] Istasse L., Gielen M., Dufrasne L., Clinquart A., Van Eenaeme C., Bienfait J.M., Ensilage de maïs plante entière, comparaison de 4 variétés. 2. Performances zootechniques, Landbouwtijdschrift Revue de l'Agriculture 43 (1990) 996-1005.

[121] Jorgenson L.R., Brown midrib in maize and its lignage relations, J. Am. Soc. Agron. 23 (1931) 549-557.

[122] Jung H.G., Allen M.S., Characteristics of plant cell wall affecting intake and digestibility of forages by ruminants, J. Anim. Sci. 73 (1995) 2774-2790.

[123] Jung H.J.G, Deetz D.A., Cell-wall lignification and degradability, in: Jung H.J.G., Buxton D.R., Hatfield R.D., Ralph J. (Eds.), Forage cell-wall structure and digestibility, American Society of Agronomy, Madison, USA, 1993, pp. 315-346.

[124] Jung H.G., Mertens D.R., Buxton D.R., Forage quality variation among maize inbreds, In vitro fiber digestion kinetics and prediction with NIRS, Crop Sci. 38 (1998) 205-210.

[125] Kauffmann C.S., Realizing the potential of grain amaranth, Food Rev. Int. 8 (1992) 5-21.

[126] Keith E.A., Colenbrander V.F., Lechtenberg V.L., Bauman L.F., Nutritional value of brown midrib corn silage for lactating dairy cows, J. Dairy Sci. 52 (1979) 788-792.

[127] Kuc J., Nelson O.E., The abnormal lignins produced by the brown midrib mutants of maize. 1. The brown-midrib-1 mutant, Arch. Biochem. Biophys. 105 (1964) 103-113.

[128] Kuehn C.S., Linn J.G., Johnson D.G., Jung H.J.G., Endre M.I., Effect of silages from corn hybrids selected for leafiness or grain to lactating dairy cattle, J. Dairy Sci. 82 (1999) 2746-2755.

[129] Kunelius H.T., Halliday L.J., Sanderson J.B., Gupta U.C., Effect of harvest dates on yield and composition of forage kale, Can. J. Plant Sci. 69 (1989) 143-149.

[130] Lam T.B.T., Iiyama K., Stone B.A., Lignin and hydroxycinnamic acids in walls of brown midrib mutants of sorghum, pearl millet and maize stems, J. Sci. Food Agric. 71 (1996) 174-178.

[131] Lancaster L.L., Hunt C.W., Miller J.C., Auld D.L., Nelson M.L., Effects of rape-seed silage variety and dietary level on digestion and 
growth performance of beef steers, J. Anim. Sci. 68 (1990) 3812-3820.

[132] Laredo M.A., Minson D.J., The voluntary intake, digestibility and retention time by sheep of leaf and stem fraction of five grasses, Aust. J. Agric. Res. 24 (1973) 875-888.

[133] Lauer J.G., Coors J.G., Flannery P.J., Forage yield and quality of corn cultivars developed in different eras, Crop Sci. 41 (2001) 1441-1455.

[134] Li L., Cheng X.F., Leshkevich J., Umezawa T., Harding S.A., Chiang V.L., The last step of syringyl monolignol biosynthesis in angiosperms is regulated by a novel gene encoding sinapyl alcohol deshydrogenase, Plant Cell 13 (2001) 1576-1585.

[135] Lila M., Barrière Y., Traineau R., Mise au point et étude d'un test enzymatique de la digestibilité de fourrages pauvres ou riches en amidon, Agronomie 6 (1986), 285-291.

[136] Lundvall J.P., Buxton D.R., Hallauer A.R., George J.R., Forage quality variation among maize inbreds: in vitro digestibility and cell wall components, Crop Sci. 34 (1994) 1672-1678.

[137] Lusk S.W., Karau P.K., Balogu D.O., Gourley L.M., Brown midrib sorghum or corn silage for milk production, J. Dairy Sci. 67 (1984) 1739-1744.

[138] Marten G.C., Barnes R.F., Prediction of energy and digestibilities of forages with in vitro rumen fermentation and fungal enzymes systems, in: Pigden W.J., Blach C.C., Graham M. (Eds.), Procedure for standardization of analytical methodology for feeds workshop, Ottawa, Canada, 1980, pp. 61-71.

[139] Méchin V., Argillier O., Barrière Y., Menanteau V., Genetic variation in stems of normal and brown-midrib3 maize inbred lines. Towards similarity for in vitro digestibility and cell-wall composition, Maydica 43 (1998) 205-210

[140] Méchin V., Argillier O., Barrière Y., Mila I., Polet B., Lapierre C., Relationships of cell-wall composition to in vitro cell-wall digestibility of maize inbred line stems, J. Sci. Food Agric. 80 (2000) 574-580.

[141] Méchin V., Argillier O., Hébert Y., Guingo E., Moreau L., Charcosset A., Barrière Y., QTL mapping and genetic analysis of cell wall digestibility and lignification in silage maize, Crop Sci. 41 (2001) 690-697

[142] Minson D.J., Wilson J.R., Prediction of intake as an element of forage quality, in: Fahey G.C. (Ed.), Forage quality, evaluation and utilization, American Society of Agronomy, Inc., Crop Science Society of America, Inc., Soil Science Society of America, Inc., Madison, Wisconsin, 1994, pp. 533-563.

[143] Moran J.B., Lemerle C., Trigg T.E., The intake and digestion of maize silage-based by dairy cows and sheep, Anim. Feed Sci. Technol. 20 (1988) 239-312.

[144] Muir J.P., Effect of dairy compost application and plant maturity on forage kenaf cultivar fiber concentration and in sacco disappearance, Crop Sci. 42 (2002) 248-254.

[145] Oba M., Allen M.S., Evaluation of the importance of the digestibility of neutral detergent fiber from forage. Effects on dry matter intake and milk yield of dairy cows, J. Dairy Sci. 82 (1999) 589-596.

[146] Oba M., Allen M.S., Effect of brown midrib 3 mutation in corn silage on productivity of dairy cows fed two concentrations of dietary neutral detergent fiber. 1. Feeding behavior and nutrient utilization, J. Dairy Sci. 83 (2000) 1333-1341.

[147] Ørskov E.R., Tait G.A.G., Reid G.W., Flachowski G., Effect of straw quality and ammonia treatment on voluntary intake, milk yield and degradation characteristics of faecal fibre, Anim. Prod. 46 (1988) 23-27.

[148] Pinçon G., Chabannes M., Lapierre C., Pollet B., Ruel K., Joseleau J.P., Boudet A.M., Legrand M., Simultaneous down-regulation of caffeic/5-hydroxyferulic acid O-methyltransferase I and cinnamoyl CoA reductase in the progeny from a cross between tobacco lines homozygous for each transgene. Consequences for plant development and lignin synthesis, Plant Physiol. 126 (2001) 145-155.

[149] Piquemal J., Lapierre C., Myton K., Schuch W., Grima-Pettenati J., Boudet A.M., Down-regulation of cinnamoyl-CoA reducase induces significant changes of lignin profiles in transgenic tobacco plants, Plant J. 13 (1998) 71-73.

[150] Piquemal J., Chamayou S., Nadaud I., Beckert M., Barrière Y., Mila I., Lapierre C., Rigau J., Puigdomenech P., Jauneau A., Digonnet C., Boudet A.M., Goffner D., Pichon M., Down-regulation of caffeic acid O-methyltransferase in maize revisited using a transgenic approach, Plant Physiol. 130 (2002) 1675-1685.

[151] Porter K.S., Axtell J.D., Lechtenberg V.L., Colenbrander V.F., Phenotype, fiber composition, and in vitro dry matter disappearance of chemically induced brown midrib (bmr) mutants of sorghum, Crop Sci. 18 (1978) 205-208.

[152] Rabinowicz P.D., Braun E.L., Wolfe A.D., Bowen B., Grotewold E., Maize R2R3 genes: Sequence analysis reveals amplification in the higher plants, Genetics 153 (1999) 427-444.

[153] Rae A.E., Manners J.M., Jones R.J., McIntyre C.L., Lu D.Y., Antisense suppression of the lignin biosynthetic enzyme, caffeate $\mathrm{O}$-methyltransferase, improves in vitro digestibility of the tropical pasture, Stylosanthes humilis, Aust. J. Plant Physiol. 28 (2001) 289-297. 
[154] Ramsey D.S., Dwarf corn for silage, J. Dairy Sci. 46 (1963) 336.

[155] Ranocha P., Chabannes M., Chamayou S., Danoun S., Jauneau A., Boudet A.M., Goffner D., Laccase down-regulation causes alterations in phenolic metabolism and cell wall structure in poplar, Plant Physiol. 129 (2002) 145-155.

[156] Reid G.W., Ørskov E.R., Kay M., A note on the effect of variety, type of straw and ammonia treatment an digestibility and on growth rate in steers, Anim. Prod. 47 (1988) 157-160.

[157] Ronsin T., Femenias N., Use of NIRS determination of digestibility in a breeding program for silage maize, in: Third international conference of near infrared spectroscopy, Brussels, 1990, pp. 277-288.

[158] Rook J.A., Muller L.D., Shank D.B., Intake and digestibility of brown midrib corn silage by lactating dairy cows, J. Dairy Sci. 60 (1977) 1894-1904.

[159] Ros Barcelo A., Peroxydase and laccase is the enzyme responsible for cell wall lignification in the secondary xylem vessels in Lupinus, Protoplasma 186 (1995) 41-44.

[160] Roussel V., Gibelin C., Fontaine A.S., Barrière Y., Genetic analysis in recombinant inbred lines of early dent forage maize. II. QTL mapping for cell wall constituents and cell wall digestibility from per se value and top cross experiments, Maydica 47 (2002) 9-20.

[161] Russell W.A., Agronomic performance of maize cultivars representing different eras of breeding, Maydica 29 (1984) 375-390.

[162] Saxena D., Stotzky G., Bt corn has a higher lignin content than non-Bt corn, Am. J. Bot. 88 (2001) 1704-1706.

[163] Sewalt V.J.H., Ni W., Jung H.J., Dixon R.A., Lignin impact on fiber degradation: Increased enzymatic digestibility of genetically engineered tobacco reduced in lignin content, J. Agric. Food Chem. 53 (1997) 1977-1983.

[164] Sleugh B.B., Moore K.J., Brummer E.C., Knapp A.D., Russell J., Gibson L., Forage nutritive value of various amaranth species at different harvest dates, Crop Sci. 41 (2001) 466-472.

[165] Sommerfeldt J.L., Schingoethe D.J., Muller L.D., Brown midrib corn silage for lactating dairy cows, J. Dairy Sci. 62 (1979) 1611-1618.

[166] Stallings C.C., Donaldson B.M., Thomas J.W., Rossman E.C., In vivo evaluation of brown-midrib corn silage by sheep and lactating dairy cows, J. Dairy Sci. 65 (1982) 1945-1949.

[167] Struik P.C., Physiology of forage maize (Zea mays L.) in relation to its productivity, Doctoral thesis, Wageningen, 1983, $97 \mathrm{p}$.

[168] Tamagone L., Merida A., Parr A., Mackay S., Culianez-Marcia F.A., Roberts K., Martin C., The AmMYB308 and AmMYB330 transcrip- tion factors from Antirrhinum regulate phenylpropanoid and lignin biosynthesis in transgenic tobacco, Plant Cell 10 (1998) 135-154.

[169] Thomas E.D., Mandebvu P., Ballard C.S., Sniffen C.J., Carter M.P., Beck J., Comparison of corn silage hybrids for yield, nutrient composition, in vitro digestibility, and milk yield by dairy cows, J. Dairy Sci. 84 (2000) 2217-2226.

[170] Tilley J.M.A., Terry R.A., A two stage technique for the in vitro digestion of forage crops, J. Brit. Grassl. Soc. 18 (1963) 104-111.

[171] Tine M.A., McLeod K.R., Erdman R.A., Baldwin R.L., Effects of brown midrib corn silage on the energy balance of dairy cattle, J. Dairy Sci. 84 (2001) 885-895.

[172] Tingle J.N., Dawley W.K., Yield and nutritive value of whole plant cereals at a silage stage, Can. J. Plant Sci. 54 (1974) 621-624.

[173] Tjardes K.E., Buskirk D.D., Allen M.S., Ames N.K., Bourquin L.D., Rust S.R., Brown midrib-3 silage improves digestion but not performance of growing beef steers, J. Anim. Sci. 78 (2000) 2957-2965.

[174] Troelson J.E., Bigsby F.W., Artificial mastication, a new approach for predicting voluntary forage consumption by ruminants, J. Anim. Sci. 23 (1964) 1139-1142.

[175] Troyer A.F., Background of US hybrid corn, Crop Sci. 39 (1999) 601-626.

[176] Troyer A.F., Germplasm ownership: related corn inbred, Crop Sci. 42 (2002) 3-11.

[177] Vadiveloo J., Varietal differences in the chemical composition and in vitro digestibility of rice straw, J. Agric. Sci. (Camb.) 119 (1992) 27-33.

[178] Van Waes J., Carlier L., Van Waes C., Van Bockstaelle E., Evaluation of quality characteristics in official trials with silage maize varieties in Belgium, Neth. J. Agric. Sci. 45 (1997) 277-289.

[179] Vignols F., Rigau J., Torres M.A., Capellades M., Puigdomènech $\mathrm{P}$., The brown midrib 3 (bm3) mutation in maize occurs in the gene encoding cafeic O-methyltransferase, Plant Cell 7 (1995) 407-416.

[180] Watanabe H., Kasuga S., Effect of brown midrib and water soluble matter content on digestibility of forage sorghum (Sorghum bicolor Moench, Sorghum sudanense Stapf) foliage, Grassland Sci. 45 (2000) 397-403.

[181] Weller R.F., Phipps R.H., The feeding value of normal and brown midrib-3 maize silage, J. Agric. Sci. 106 (1986) 31-35.

[182] Wilson W.A., Harrington S.E., Woodman W.L., Lee M., Sorrells M.E., McCouch S., Inferences on the genome structure of progenitor maize through comparative analysis of rice, maize 
and the domesticated panicoids, Genetics 153 (1999) 453-473.

[183] Wolf D.P., Coors J.G., Albrecht K.A., Undersander D.J., Carter P.R., Forage quality of maize genotypes selected for extreme fiber concentrations, Crop Sci. 33 (1993) 1353-1359.

[184] Xiccato G., Trocino A., Carazzolo A., Ensiling and nutritive value of kenaf (Hibiscus cannabinus), Anim. Feed Sci. Technol. 71 (1998) 229-240.
[185] Zimmer E., Theune H.H., Wermke M., Estimation of the nutritive value of silage maize by using chemical parameters and in vitro digestibility, in: Pollmer W.G, Phipps R.H. (Eds.), Improvement of quality traits of maize for grain and silage use, M. Nijhoff Publih., 1980, pp. 447-462.

[186] Zimmer E., Criteria and methods for evaluation of silage maize, in: Proceedings of Eucarpia maize and Sorghum congress, Baden, Austria, 1990, pp. 214-222.

To access this journal online: www.edpsciences.org 